EGG-ER-11005

Rev. 0

\title{
Idaho National Engineering Laboratory Analytical Services Performance Evaluation Plan
}

J. M. Connolly

S. J. Sailer

D. A. Anderson

Published March 1994

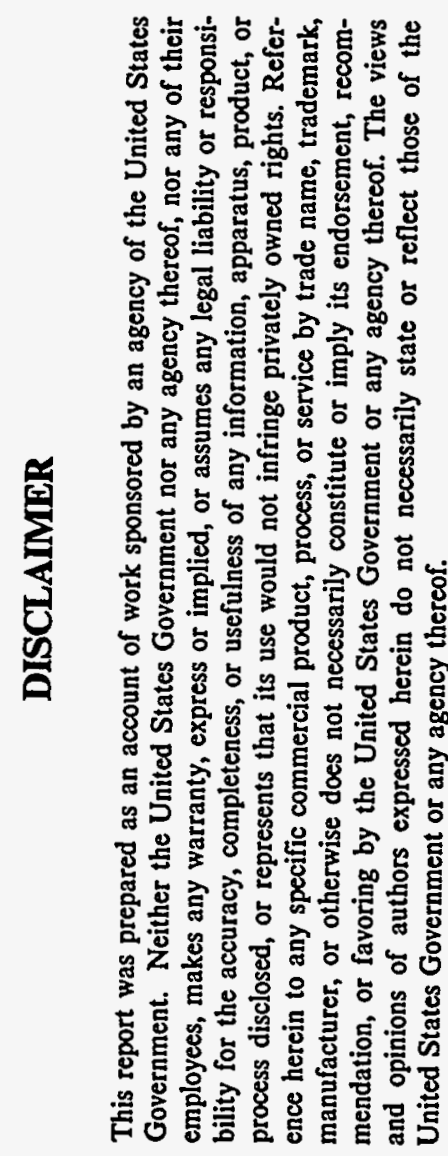

Idaho National Engineering Laboratory

EG\&G Idaho, Inc.

Idaho Falls, Idaho 83415

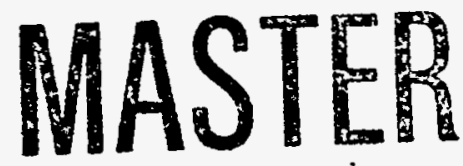

Prepared for the

U.S. Department of Energy

Assistant Secretary for Environmental Restoration and Waste Management

Under DOE Idaho Operations Office

Contract DE-AC07-76ID01570

DISTRIBUTION OF THIS DOCURANT IS UNMIRMTE 


\section{DISCLAIMER}

Portions of this document may be illegible in electronic image products. Images are produced from the best available original document. 


\title{
Idaho National Engineering Laboratory Analytical Services Performance Evaluation Plan
}

\author{
EGG-ER-11005 \\ Revision 0 \\ March 1994
}

Approved by

Ry.hrm

R. J. Bargelt, Unit Manager

ER Planning and Integration Unit

EG\&G Idaho, Inc.
$3-16-94$

Date

Reviewed by

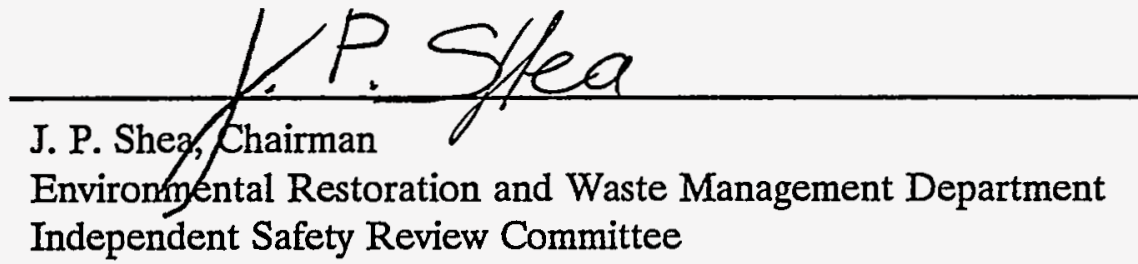

$3 \cdot 16-94$

Date

Independent Safety Review Committee

Author

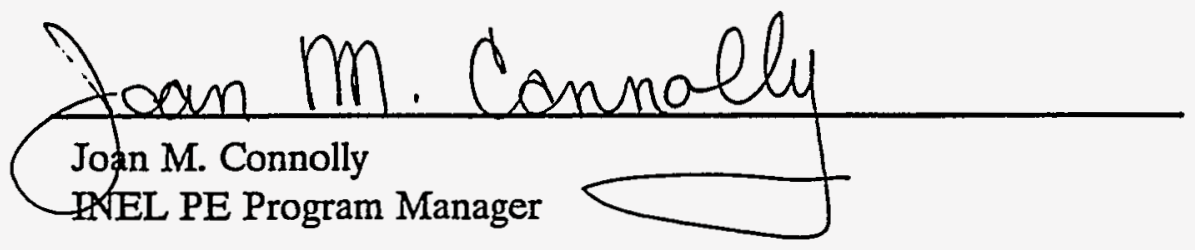

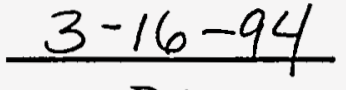

Date 


\begin{abstract}
The Idaho National Engineering Laboratory's (INEL's) Sample Management Office (SMO) conducts a Performance Evaluation Program that ensures that data of known quality are supplied by the analytical . chemistry service organizations with which the INEL contracts. The Analytical Services Performance Evaluation Plan documents the routine monitoring and assessment of suppliers conducted by the SMO, and it describes the procedures that are followed to ensure that suppliers meet all appropriate requirements.
\end{abstract}




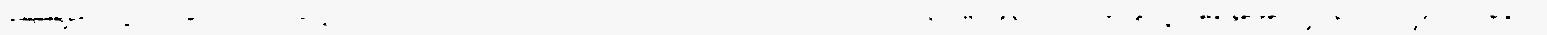




\section{CONTENTS}

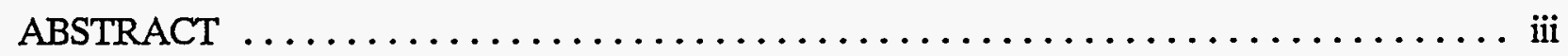

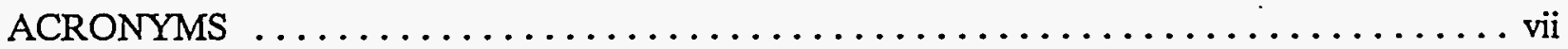

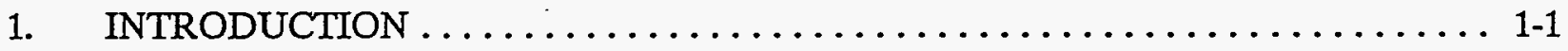

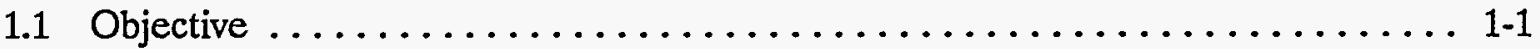

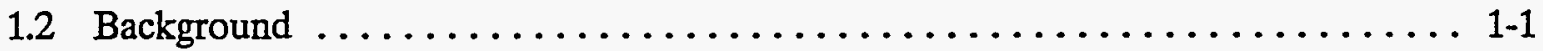

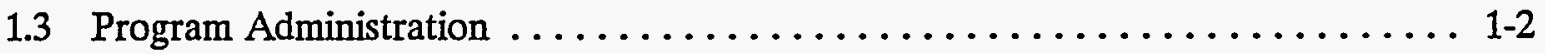

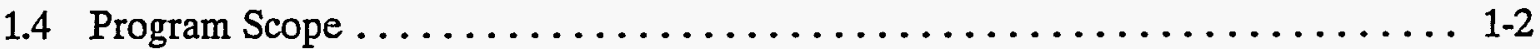

1.4.1 Suppliers and Analytical Disciplines Assessed $\ldots \ldots \ldots \ldots \ldots \ldots \ldots$ 1-2

1.4.2 PE Program Components .......................... 1-3

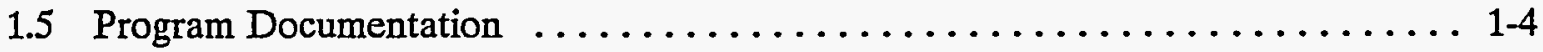

2. ORGANIZATION AND PERSONNEL RESPONSIBILITIES $\ldots \ldots \ldots \ldots \ldots \ldots .2-1$

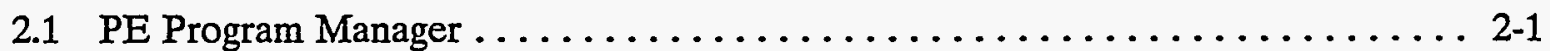

2.2 PE Program Quality Assurance (QA) Officer $\ldots \ldots \ldots \ldots \ldots \ldots \ldots \ldots \ldots \ldots \ldots \ldots \ldots$

2.3 PE Program Statistician $\ldots \ldots \ldots \ldots \ldots \ldots \ldots \ldots \ldots \ldots \ldots \ldots \ldots \ldots \ldots \ldots \ldots \ldots \ldots .1$

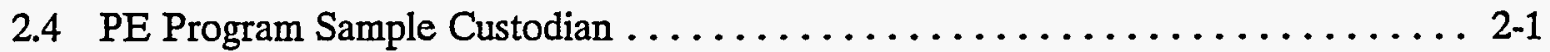

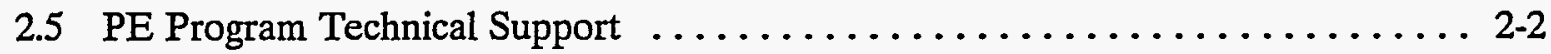

2.6 PE Program Document Controller $\ldots \ldots \ldots \ldots \ldots \ldots \ldots \ldots \ldots \ldots \ldots \ldots \ldots \ldots \ldots \ldots \ldots \ldots$

2.7 Procurement Interface $\ldots \ldots \ldots \ldots \ldots \ldots \ldots \ldots \ldots \ldots \ldots \ldots \ldots \ldots \ldots \ldots \ldots \ldots \ldots .2$

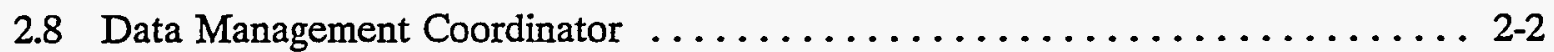

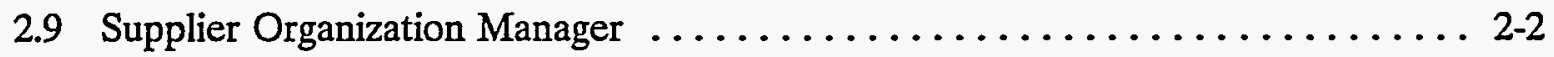

2.10 Supplier Organization Program Manager $\ldots \ldots \ldots \ldots \ldots \ldots \ldots \ldots \ldots .2-2$

2.11 Laboratory QA Officer $\ldots \ldots \ldots \ldots \ldots \ldots \ldots \ldots \ldots \ldots \ldots \ldots \ldots \ldots \ldots \ldots \ldots$

3. PERFORMANCE EVALUATION TOOLS $\ldots \ldots \ldots \ldots \ldots \ldots \ldots \ldots \ldots \ldots \ldots . \ldots \ldots$

3.1 Tools for Analytical Laboratory Performance Evaluation $\ldots \ldots \ldots \ldots \ldots \ldots$ 3-1 
Rev. 0

3.1.1 General Laboratory Operation Performance ............... 3-1

3.1.2 Analytical Discipline or Method-Specific Laboratory Performance . . . . . 3 3-2

3.2 Tools for Evaluation of Data Validator Performance $\ldots \ldots \ldots \ldots \ldots \ldots \ldots$

3.2.1 Audits or Desk Evaluations . . . . . . . . . . . . . . . . 3

3.2.2 Assessment of Deliverables . . . . . . . . . . . . . . .

3.2.3 Dual Validation of Data Packages . . . . . . . . . . . . . . $3-8$

3.2.4 Blind Test Data Packages ..................... 3.8

4. PERFORMANCE INDICATORS AND PERFORMANCE ASSESSMENT . . . . . . 4-1

4.1 Performance Indicators and Performance Criteria ............... 4-1

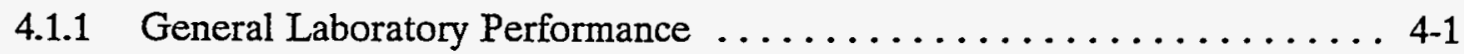

4.1.2 Analysis-Specific Laboratory Performance Indicators . . . . . . . . . . 4-3

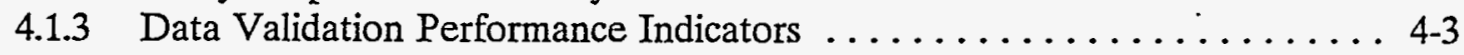

4.2 Indicator Assessment Process $\ldots \ldots \ldots \ldots \ldots \ldots \ldots \ldots \ldots \ldots \ldots \ldots$

4.2.1 Indicator Tracking and Trending $\ldots \ldots \ldots \ldots \ldots \ldots \ldots \ldots \ldots \ldots$

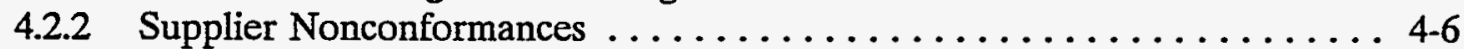

4.2 .3 Variances $\ldots \ldots \ldots \ldots \ldots \ldots \ldots \ldots \ldots \ldots \ldots \ldots \ldots \ldots . \ldots \ldots$

5. PERFORMANCE STATUS $\ldots \ldots \ldots \ldots \ldots \ldots \ldots \ldots \ldots \ldots \ldots \ldots \ldots$

5.1 Performance Status Change $\ldots \ldots \ldots \ldots \ldots \ldots \ldots \ldots \ldots \ldots \ldots \ldots \ldots \ldots \ldots$

5.2 Performance Status Classifications $\ldots \ldots \ldots \ldots \ldots \ldots \ldots \ldots \ldots$

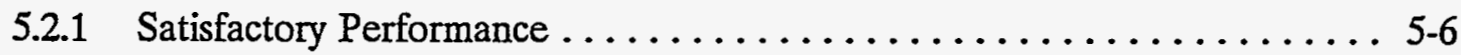

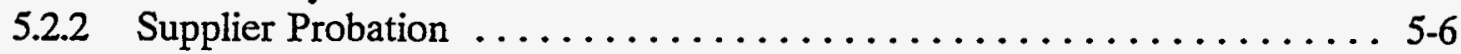

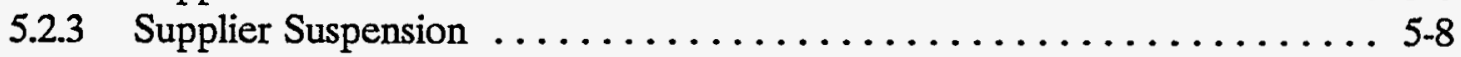

5.2 .4 Termination of SMO Approval $\ldots \ldots \ldots \ldots \ldots \ldots \ldots \ldots \ldots \ldots \ldots . \ldots \ldots$

5.3 Reporting of Performance Assessments and Status . . . . . . . . . . . 5-10

6. RECORDS MANAGEMENT AND RETENTION ................ $6-1$

6.1 Documentation Requirements $\ldots \ldots \ldots \ldots \ldots \ldots \ldots \ldots \ldots \ldots \ldots \ldots$

6.2 Computer Databases, Statistical Software, and Networks ........... 6-1

7. QUALITY ASSURANCE REQUIREMENTS $\ldots \ldots \ldots \ldots \ldots \ldots \ldots \ldots \ldots \ldots \ldots$ 7-1

7.1 Program Requirements $\ldots \ldots \ldots \ldots \ldots \ldots \ldots \ldots \ldots \ldots \ldots \ldots \ldots \ldots \ldots \ldots$

7.2 Nonconformances and Corrective Actions $\ldots \ldots \ldots \ldots \ldots \ldots \ldots \ldots$ 
7.3 QA Reports to Management $\ldots \ldots \ldots \ldots \ldots \ldots \ldots \ldots \ldots \ldots \ldots \ldots \ldots \ldots \ldots \ldots$

8. ASPEP IMPLEMENTATION $\ldots \ldots \ldots \ldots \ldots \ldots \ldots \ldots \ldots \ldots \ldots \ldots \ldots \ldots$

8.1 Implementing Documentation $\ldots \ldots \ldots \ldots \ldots \ldots \ldots \ldots \ldots \ldots \ldots \ldots$

8.2 Performance Evaluation Tools $\ldots \ldots \ldots \ldots \ldots \ldots \ldots \ldots \ldots \ldots \ldots . \ldots . \ldots$

8.3 Pilot Phase $\ldots \ldots \ldots \ldots \ldots \ldots \ldots \ldots \ldots \ldots \ldots \ldots \ldots \ldots \ldots \ldots \ldots$

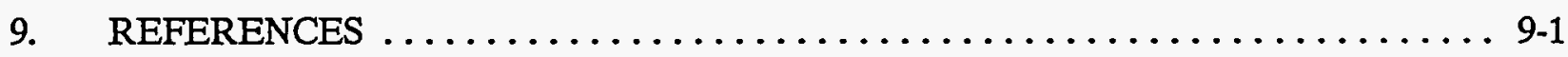

FIGURES

4-1. Example of Supplier Nonconformance/Trend Condition Notification Form. . . . . . . 4-7

4-2. Example of Record of Variance Form. ..................... $4-9$

5-1. Supplier Performance Status Classification Pathways. ............... 5-2

5-2. Example of Notification of Performance Status Change Form . . . . . . . . . . 5-5

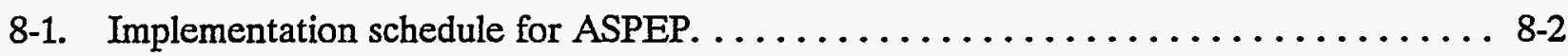

\section{TABLES}

3-1. Required participation in existing PE programs.

4-1. General laboratory operations performance indicators and acceptable performance

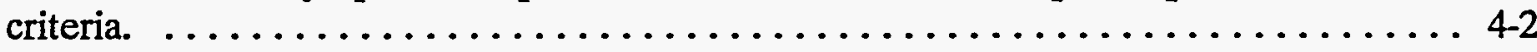

4-2. Analysis-specific laboratory performance indicators and acceptable performance criteria. .................................. $4-4$

4-3. Data validation performance indicators and acceptable performance criteria. ...... 4-5

5-1. Grounds for change in laboratory performance status. $\ldots \ldots \ldots \ldots \ldots \ldots \ldots \ldots$

5-2. Grounds for change in data validator performance status. . . . . . . . . . . 5-4

5-3. Supplier performance status resolution. $\ldots \ldots \ldots \ldots \ldots \ldots \ldots \ldots \ldots \ldots \ldots \ldots \ldots$ 


\section{ACRONYMS}

AALA

ARDC

ASPEP

CA

CAA

CAQ

CERCLA

CLP

$\mathrm{COC}$

CP

CRDL

CRA

CRI

CRQL

CVAAS

CWA

DMC

DOE

DOE-ID

EM

EML

EMSL-CI

EMSL-LV
American Association for Laboratory Accreditation

Administrative Record and Document Control

Analytical Services Performance Evaluation Plan

corrective action

Clean Air Act

condition adverse to quality

Comprehensive Environmental Response, Compensation, and Liability Act

Contract Laboratory Program

chain of custody

Company Procedure

contract-required detection limit

detection-level QC standard for GFAAS or ICP-MS

detection-level QC standard for ICP-AES or FAAS

contract-required quantitation limit

cold vapor atomic absorption

Clean Water Act

data management coordinator

U.S. Department of Energy

U.S. Department of Energy Idaho Operations Office

Environmental Management

Environmental Measurements Laboratory

Environmental Monitoring Systems Laboratory, Cincinnati

Environmental Monitoring Systems Laboratory, Las Vegas 
ERA Environmental Resource Associates

ERD Environmental Restoration Department

ERIS Environmental Restoration Information System

EPA U.S. Environmental Protection Agency

ER Environmental Restoration

ER\&WM Environmental Restoration and Waste Management

FAAS flame atomic absorption spectrometry

FFA/CO Federal Facility Agreement and Consent Order

FTE full-time equivalent

FY fiscal year

GC gas chromatography

GCMS gas chromatography mass spectrometry

GFAAS graphite furnace atomic absorption spectrometry

GOCO government-owned contractor-operated

HAAS hydride atomic absorption spectrometry

HPLC high-performance liquid chromatography

ICP-AES inductively coupled plasma atomic emission spectrometry

ICP-MS inductively coupled plasma mass spectrometry

ICSA interference check sample, Part A

ICSAB interference check sample, Part $A+$ Part $B$

IEDMS Integrated Environmental Data Management System

INEL Idaho National Engineering Laboratory

$\mathrm{L} \& \mathrm{~V} \quad \cdot$ limitations and validation

LCS laboratory control sample

MAPEP Mixed Analyte Performance Evaluation Program 


\begin{tabular}{ll} 
MRDL & method-required detection limit \\
NIST & National Institute of Standards and Technology \\
OP & operating procedure \\
PCB & polychlorinated biphenyl \\
PD & Project Directive \\
PDP & Performance Demonstration Program \\
PE & performance evaluation \\
PESM & performance evaluation soil material \\
PRQL & program-required quantitation limit \\
QA & quality assurance \\
QAP & Quality Assessment Program \\
QB & quarterly blind \\
QC & quality control \\
QAPjP & Quality Assurance Project Plan \\
R & recovery \\
RCRA & Resource Recovery and Conservation Act \\
RESL & Radiological and Environmental Sciences Laboratory \\
RFP & Request for Proposal \\
RIS & Radiological Intercomparison Study \\
SCM & site-characterized material \\
SDG & Sample Delivery Group \\
SDWA & Safe Drinking Water Act \\
SMO & Sample Management Office \\
SNC & surd Operating Procedure \\
\hline
\end{tabular}


EGG-ER-11005

Rev. 0

SOW

Statement of Work

SRAU

Statistics Reliability and Analysis Unit

SSR

Systems Subcontract Release

SVOC semivolatile organic compound

TAL

Target Analyte List

TC

trend condition

TCL

Target Compound List

TOS

Task Order Statement of Work

USGS

U.S. Geological Survey

VOC

volatile organic compound

VTSR

verified time of sample receipt

WIPP

Waste Isolation Pilot Plant

WM

Waste Management

WP

water pollution

WS

water supply 


\section{Idaho National Engineering Laboratory Analytical Services Performance Evaluation Plan}

\section{INTRODUCTION}

\subsection{Objective}

The primary responsibility of the Idaho National Engineering Laboratory's (INEL's) Sample Management Office (SMO) is to ensure that data of known quality are supplied to the INEL by analytical chemistry service organizations. Because high-quality analytical support is vital to the success of DOE Environmental Management (EM) programs at the INEL, the performance of organizations providing these services must be routinely monitored and assessed. This will be accomplished through the implementation of a Performance Evaluation (PE) Program.

The INEL Analytical Services Performance Evaluation Plan (ASPEP) documents the approach of the INEL PE program. The framework described in this document will ensure that laboratory and validator analytical service suppliers used by the SMO meet requirements and maintain an appropriate quality level.

\subsection{Background}

U.S. Department of Energy (DOE) Order 5700.6D, Quality Assurance, states that it is the responsibility of DOE contractors to ensure that "quality is achieved and maintained by those who have been assigned the responsibility for performing the work." It is, therefore, imperative that products and services supporting DOE EM (environmental monitoring, environmental restoration, and waste management) analytical needs meet appropriate quality standards.

A joint statement issued by DOE, the U.S. Environmental Protection Agency (EPA) and the Department of Defense, ${ }^{1}$ and a subsequent DOE memorandum, ${ }^{a}$ emphasize the need to develop and implement a consistent and innovative means of preventing and identifying data falsification. Past occurrences of fraud in the generation of environmental and waste characterization data have been detrimental to the credibility of the DOE. A recent proposed Federal Register rule ${ }^{2}$ indicates that DOE will not be able to rely on other agencies for notification of suspect laboratories or validators.

The INEL PE program was developed and the ASPEP written to address the requirements of DOE Order 5700.6D and to provide DOE-ID with a proactive tool to prevent and detect the occurrence of unethical behavior by analytical service suppliers. The PE program measures acceptable performance through tracking and evaluating performance indicators. This system provides an objective means for the prevention and detection of suspect analytical products.

a. U.S. Department of Energy, EH-231, Memorandum to Distribution, Subject: "Integrity of Environmental Analytical Data," November 4, 1991. 
Rev. 0

\subsection{Program Administration}

The PE program, i.e., implementation of the ASPEP, is the responsibility of the INEL PE Program Office. This office is an integral part of the INEL SMO plus matrixed organizations and is not intended to be a separate organization. Existing systems, such as the Integrated Environmental Data Management System (IEDMS) and the Environmental Restoration Information System (ERIS), and their current support staffs will be used, whenever possible, to implement this plan. Section 2 discusses specific organizational structure and responsibilities.

\subsection{Program Scope}

The INEL ASPEP is an integrated approach across EM that addresses Comprehensive Environmental Response, Compensation, and Liability Act-(CERCLA) specific supplier evaluations as well as evaluations of Safe Drinking Water Act (SDWA), Clean Water Act (CWA), Resource Conservation and Recovery Act (RCRA) and Clean Air Act (CAA) analytical services. SMO-contracted analytical service suppliers supporting customers across EM programs are subject to the requirements defined in this document. Analytical support to the INEL obtained by organizations other than the SMO are not subject to the requirements of this document.

The intent of the INEL PE program is to augment existing PE programs administered by EPA and DOE by expanding into areas not addressed by these programs. Supplier performance monitoring based on existing PE program results, while useful, occurs too infrequently to allow prompt correction of quality problems. The ASPEP combines existing PE program performance data with real-time laboratory assessment data and evaluation of data validation suppliers.

\subsubsection{Suppliers and Analytical Disciplines Assessed}

Analytical service suppliers evaluated through the INEL PE program include analytical laboratory support and analytical data validation support. These suppliers may be government contractors (GOCOs), on-site commercial mobile laboratories, or off-site commercial subcontractors. Each analytical service supplier has been subject to an initial approval process by the INEL SMO prior to contract award. The ASPEP defines a mechanism for continuing assessment of supplier performance after contract award to ensure that acceptable performance is maintained for the duration of the contract.

Performance indicators are chosen to assess overall performance by the service organization and performance on a specific analyte, method or matrix, analysis type and analytical discipline basis, as appropriate. Performance indicators are tracked for each service supplier and analyzed for trends and compliance with PE program requirements. Analysis of these performance indicators allows the PE Program Office to identify and expedite resolution of supplier performance deficiencies, thus minimizing adverse impact on INEL programs.

Analytical disciplines for which performance is monitored include metals, organics, radiochemical, and miscellaneous classical analysis methods. These analytical disciplines are defined as follows: 
1.4.1.1 Metals. For purposes of this program, metals refers to analysis of all elements which are included on the EPA Contract Laboratory Program (CLP) Target Analyte List (TAL), ${ }^{3}$ regulated by $\mathrm{RCRA}^{4}$ or regulated under the SDWA and the CWA. ${ }^{5}$ Elements not included on these lists may be examined as special cases. Analysis types within the metals discipline are differentiated by the type of instrumentation used. Inductively coupled plasma atomic emission spectrometry (ICP-AES) and inductively coupled plasma mass spectrometry (ICP-MS) are grouped together as "ICP metals" because of their common excitation source. Atomic absorption techniques are divided into three analysis types based on their atomization sources: graphite furnace atomic absorption spectrometry (GFAAS), flame atomic absorption spectrometry (FAAS), and cold vapor or hydride atomic absorption spectrometry (CVAAS or HAAS).

1.4.1.2 Organics. Organic analytes encompass the following analysis types: volatile organic compounds (VOCs), semivolatile organic compounds (SVOCs), pesticides, and polychlorinated biphenyls (PCBs). Analytical performance for those analytes included on the EPA CLP Target Compound List (TCL), ${ }^{6}$ or regulated by RCRA, SDWA, or CWA are monitored. Organic analysis instrumentation may include gas chromatography (GC), gas chromatography mass spectrometry (GCMS) and high-performance liquid chromatography (HPLC). Other organic analyses, such as herbicides, dioxins and furans, will be examined on an as-needed basis.

1.4.1.3 Radiochemistry. Radiochemical analyses encompass the analysis types of alpha, beta, and gamma determinations, and refers to both radiological screening techniques (gross alpha, gross beta, and gamma) and isotope-specific quantitation techniques (alpha spectrometry, beta isotopic analyses, and gamma spectrometry).

1.4.1.4 Classicals. Miscellaneous classical analyses encompass methods which are not within the other classifications and are required to support CERCLA, RCRA, SDWA, CWA or CAA (e.g., nutrients, minerals, hardness, demand, and cyanide). Method performance will be routinely monitored for only those methods used on a regular basis for INEL samples (e.g., anions, total organic carbon, and cyanide). Because classical analyses are so diverse, there is no differentiation by analysis type defined within the discipline.

\subsubsection{PE Program Components}

The ASPEP integrates periodic and real-time supplier performance evaluation with quality improvement tools for a comprehensive approach to analytical service quality management. Tools for assessing performance are identified in Section 3 of this document. Performance indicators are associated with each evaluation tool and acceptable performance levels are established for each indicator. Performance assessment tools and their associated indicators fit into one of the following approaches to quality assurance:

1. Periodic Supplier Performance Evaluation: consists of evaluation of laboratory performance data generated from participation in existing $P E$ programs administered by EPA or DOE, supplier audits, and evaluation of data validator performance on blind prevalidated data packages.

2. Real-time Supplier Performance Evaluation: consists of evaluation of laboratory quality control (QC) and blind PE sample data generated concurrently with INEL field 
Rev. 0

samples, assessment of performance indicators associated with supplier management practices, and evaluation of supplier deliverables.

3. Quality Improvement: consist of matrix-specific QC materials provided to suppliers for use as known laboratory controls and feedback on periodic and real-time performance evaluations for use in process improvements.

Data generated by participation in existing PE programs will be used as a tool to determine the general ability of a supplier to perform the required work. However, existing PE programs administered by EPA or DOE primarily manage quality by inspection because they are too infrequent to ensure that real-time control of data quality is maintained. The INEL ASPEP addresses quality through prevention, and augments data available from existing PE programs by:

1. Use of real-time quality assurance tools to monitor laboratory and validator performance when INEL samples or data packages are being processed

2. Performance assessment of validation support suppliers

3. Creation and use of INEL-specific PE soil samples

4. Use of commercially available PE samples

5. Tracking performance indicators that reflect supplier management practices.

One benefit of these enhancements is that INEL project managers will have a broader base of performance data available to support decision making processes. The INEL-specific performance evaluation soil samples provide a better means to identify and correct analytical problems affecting actual INEL soil sample analyses. The evaluation of INEL-specific performance data from items one through four above provides a mechanism to detect quality problems close to real-time and prevent future recurrences.

\subsection{Program Documentation}

The ASPEP defines the requirements for the PE Program. Specific requirements and implementation detail of some elements of the program (e.g., development of INEL-specific PE materials) will be defined and documented in Quality Assurance Project Plans (QAPjPs), Statements of Work (SOWs), Standard Operating Procedures (SOPs), and work plans, as appropriate for the level of review and control required. 


\section{ORGANIZATION AND PERSONNEL RESPONSIBILITIES}

Functional responsibilities required for the ASPEP are described in this section. An official listing of key personnel shall be maintained in PE Program files and updated as changes occur. Eight functional responsibilities within EG\&G Idaho are defined for the ASPEP, and comprise the PE Program Office. However, because responsibilities are not full-time efforts, the number of functional responsibilities does not reflect the number of full-time equivalents (FTEs) of support required.

\subsection{PE Program Manager}

The PE Program Manager is responsible for all operational aspects of the program. The Program Manager is responsible for ensuring that all program plans, QAPjPs, SOWs, and SOPs required for this program are prepared. The Program Manager oversees implementation of the program in accordance with the Program Management Plan, manages the program budget and schedule, and ensures the availability of necessary personnel, equipment, and services. The Program Manager, together with the EG\&G Idaho Procurement organization, is responsible for ensuring that analytical suppliers are notified of their performance assessment on a routine basis, and for interfacing with them during problem resolution. The PE Program Manager is also responsible for providing feedback on supplier performance to appropriate EG\&G Idaho program managers.

\subsection{PE Program Quality Assurance (QA) Officer}

The PE Program QA Officer is responsible for ensuring that all quality requirements of the program are met as specified in this document. The Program QA Officer shall provide routine guidance on quality-related matters to program staff. The Program QA Officer shall identify and report quality problems within the PE Program to the PE Program Manager, and shall initiate, recommend, and track associated corrective actions to closure. The Program QA Officer also reviews instances of supplier nonconformance and any associated corrective actions.

\subsection{PE Program Statistician}

The PE Program Statistician is responsible for developing, validating and implementing statistical procedures for assessing performance indicators. The Program Statistician ensures that the statistical procedures are accurately documented in SOPs, and oversees routine analyses of performance indicators in accordance with these procedures. The Program Statistician is responsible for evaluating and acquiring any statistical software packages needed for the analysis of performance indicators. The Program Statistician also provides technical support as required to assist the Program Manager with experimental design and data analysis.

\subsection{PE Program Sample Custodian}

The Program Sample Custodian is responsible for coordinating all sample tracking activities associated with any PE program materials which are submitted by the PE Program Office to suppliers. The Program Sample Custodian maintains a tracking database for PE material custody 
Rev. 0

and characterization data, prepares appropriate SOPs, and interacts with designated sample custodians at the analytical support laboratories.

\subsection{PE Program Technical Support}

Technical support person(s) are technical experts in the areas evaluated by the program and provide technical support for preparation of project documentation and data interpretation as required.

\subsection{PE Program Document Controller}

The Environmental Restoration and Waste Management Department Administrative Record and Document Control (ARDC) organization serves as the Program Document Controller. The ARDC maintains all PE Program controlled documents and maintains a filing system for the storage of all administrative and technical documents. Specific ARDC responsibilities are delineated in ER-PD-4.1, Document Control. ${ }^{7}$

\subsection{Procurement Interface}

The Environmental and Waste Management Acquisitions Unit of EG\&G Idaho works with the PE Program Manager to ensure that interactions with supplier organizations are handled in accordance with company procedures and federal acquisitions requirements. All communication with supplier organizations dealing with supplier performance status must have direct EG\&G Idaho Procurement involvement.

\subsection{Data Management Coordinator}

The Data Management Coordinator (DMC) is responsible for checking completeness of laboratory deliverables, maintaining all performance indicator and performance status databases (using IEDMS) and appropriate operating procedures, and producing performance indicator charts. The DMC also provides the interface to ERIS.

\subsection{Supplier Organization Manager}

The manager of each supplier organization providing analytical support services has overall responsibility for ensuring that the services are provided in accordance with appropriate INEL SMO SOWs and SOPs, and for ensuring that any required corrective action is resolved in a timely fashion.

\subsection{Supplier Organization Program Manager}

The Supplier Organization Program Manager is the person within each service organization responsible for overseeing services requested by the INEL SMO and interfacing with the PE Program Manager regarding service organization performance. The Supplier Program Manager and the Supplier Organization Manager may be the same individual in many cases. 


\subsection{Laboratory QA Officer}

All analytical laboratories used by the INEL SMO must identify a laboratory QA Officer to oversee their QA program and provide independent oversight of laboratory operations. The laboratory QA Officer is responsible for ensuring that all data released by the laboratory meet the requirements specified in the SOW provided by the INEL SMO. The laboratory QA officer will provide the PE Program Manager with historical laboratory performance data and shall coordinate with the PE Program Manager to submit internally-prepared blind PE materials to the laboratory as requested. 


\section{PERFORMANCE EVALUATION TOOLS}

This section summarizes tools used to evaluate the performance of analytical support suppliers and the required frequency of their use. These tools include supplier audits, inspection of supplier deliverables, submission of $\mathrm{PE}$ materials blind to the suppliers, use of site-specific laboratory control samples (LCSs) and existing PE program data. These tools are selected to provide information regarding the supplier's management practices as well as their performance in specific analytical disciplines.

For purposes of this discussion, PE tools are referred to as "periodic" or "real-time", depending on the nature of their use. Periodic tools are used at a set frequency to provide information on supplier performance, either general or discipline-specific, which is not specifically associated with a particular batch of INEL field samples. Information supplied by periodic PE tools is indicative of overall performance or capabilities in a particular analytical discipline or method. Information provided by real-time PE tools is directly associated with supplier performance on specific batches of INEL field samples. Real-time tools are those which are either processed by the supplier at the same time as INEL field samples (e.g., a blind PE sample or laboratory QC) or data (e.g., a blind previously-validated data package) or involve assessment of supplier deliverables for actual INEL field samples.

\subsection{Tools for Analytical Laboratory Performance Evaluation}

\subsubsection{General Laboratory Operation Performance}

Three performance tools are used to evaluate general laboratory operations: on-site audits, desk evaluations, and assessment of deliverables. These tools are discussed below in greater detail.

3.1.1.1 On-Site Laboratory Audits. Laboratory audits are used as periodic tools to assess laboratory capability to perform in accordance with master subcontract requirements. As a prerequisite to participation in the INEL PE program, each analytical laboratory must pass an initial audit to become SMO-approved. Thereafter, each analytical laboratory is audited on an annual basis. These audits may be performed by INEL audit personnel or by personnel from other DOE facilities, and cover general laboratory operation plus all analytical disciplines supported by the laboratory. As a condition of contract, all analytical laboratories must respond to findings incurred during an on-site audit.

3.1.1.2 Desk Evaluations. Desk evaluations may be used in place of the annual on-site laboratory audit. A desk evaluation includes review of the laboratory QA manual, past audit reports, any revised laboratory procedures, organization and personnel qualifications, user references, performance and product history, industry certifications, and internal QA practices. If major problems are identified during a desk evaluation, an on-site audit may be required.

3.1.1.3 Assessment of Deliverables. Assessment of analytical laboratory deliverables against Statement of Work (SOW), Task Order Statement of Work (TOS) or Systems Subcontract Release (SSR) requirements is used as a real-time evaluation tool for general analytical laboratory operations. The deliverable (data package) is evaluated for compliance with holding times, turnaround times, completeness and accuracy, as well as adherence to other 
Rev. 0

specified requirements. This assessment may be performed in two stages; all deliverables receive an initial quick overview (Level B or C validation) ${ }^{8}$ by the INEL SMO upon receipt, and some receive a more detailed assessment (Level $A$ validation $)^{8}$ by a data validator. A limitations and validation $(\mathrm{L \& V})$ report is completed by a validator to summarize the quality of the deliverable. Based on the deliverable assessment, corrective action by the laboratory may be required.

\subsubsection{Analytical Discipline or Method-Specific Laboratory Performance}

Five evaluation tools are used to evaluate laboratory performance within specific analytical disciplines or particular analytical methods: participation in existing PE programs, analysis of INEL-specific PE samples, splits of field samples, spikes of field samples, and routine laboratory QC samples. These tools are discussed in detail in the following subsections.

3.1.2.1 Participation in Existing PE Programs. Results of participation in existing programs within the environmental analysis industry are used as periodic checks of laboratory capabilities in specific analytical disciplines or methods. As a condition of contract, analytical laboratories are required to participate in certain programs for all sample matrices and analytical disciplines or methods for which they provide support to the INEL. The requirements for participation come from several sources: Federal mandates (e.g., EPA CLP QB for CERCLA support); state certification (e.g., drinking water analyses); DOE mandates (e.g., QAP and RIS), or the INEL PE program requirements. Costs associated with participation in these programs shall be absorbed by the laboratories as a cost of doing business with the INEL SMO. As a condition of contract, analytical laboratories must agree to make the results of their participation in these programs available to the PE Program Office.

Materials used in existing programs are formulated by those programs to meet their own needs. While these materials are extensively characterized, the matrix, choice of analytes and concentration levels may not match those of actual INEL field samples. Thus, the ability to successfully analyze these materials may not reflect the ability to successfully analyze INEL samples. Therefore, results from participation in these programs are used by the INEL PE program to assess the general ability of a laboratory to perform on a generic matrix.

Required participation in existing PE programs is outlined below and summarized in Table 3-1.

1. Environmental Monitoring Systems Laboratory, Las Vegas (EMSL-LV) Radiological Intercomparison Study (RIS): All laboratories providing radiochemical services (gross radiological screening as well as specific radionuclide analyses) must participate in at least two of the three studies conducted per year for all matrices (water and air filters).

2. Environmental Measurements Laboratory (EML) Quality Assessment Program (QAP): All laboratories providing radiochemical services must participate semiannually in the QAP for all available matrices (water, soil, air filters and biota).

3. EPA CLP Quarterly Blind $(Q B)$ Performance Evaluation: All analytical laboratories supporting metals, VOC, SVOC, pesticide/PCB or cyanide analyses via CLP methods must participate in the $\mathrm{QB}$ program for those analytical disciplines and matrices applicable to the support provided by the laboratory. Laboratories supporting SDWA analyses only are exempt from required CLP QB participation. Those analytical 
Table 3-1. Required participation in existing PE programs.

\begin{tabular}{|c|c|c|c|c|c|c|c|c|c|c|c|c|c|}
\hline \multirow{2}{*}{\multicolumn{2}{|c|}{$\begin{array}{c}\text { Existing Performance Evaluation Programs } \\
\text { and } \\
\text { Required Participation Frequency }\end{array}$}} & \multicolumn{12}{|c|}{ Idaho National Engineering Laboratory Environmental Program } \\
\hline & & \multicolumn{4}{|c|}{ Environmental Restoration } & \multicolumn{4}{|c|}{ Waste Management } & \multicolumn{4}{|c|}{ Environmental Monitoring } \\
\hline & $\begin{array}{c}\text { Mandate } \\
\text { Source }\end{array}$ & Rad & Org & Metals & Other & Rad & Org & Metals & Other & Rad & Org & Metals & Other \\
\hline $\begin{array}{c}\text { EMSL RIS } \\
\text { Semiannual }\end{array}$ & DOE & $\mathrm{F}, \mathrm{W}$ & & & & $\mathrm{F}, \mathrm{W}$ & & & & $F, W$ & & & \\
\hline $\begin{array}{l}\text { EML QAP } \\
\text { Semiannual }\end{array}$ & DOE & $\begin{array}{c}\mathrm{F}, \mathrm{W} \\
\mathrm{S}, \mathrm{B}\end{array}$ & & & & $\begin{array}{c}\mathrm{F}, \mathrm{W} \\
\mathrm{S}, \mathrm{B}\end{array}$ & & & & $\begin{array}{c}\mathrm{F}, \mathrm{W} \\
\text { S,B }\end{array}$ & & & \\
\hline $\begin{array}{l}\text { USEPA CLP QB } \\
\text { Semiannual }\end{array}$ & \begin{tabular}{|c|} 
CERCLA \& \\
INEL ASPEP
\end{tabular} & & $\mathbf{W}, \mathbf{S}$ & $\mathbf{W , S}$ & $\begin{array}{l}\mathrm{W}, \mathrm{S} \\
(\mathrm{CN})\end{array}$ & & W,S & $\mathrm{W}, \mathrm{S}$ & & & & & \\
\hline $\begin{array}{c}\text { EMSL-CI WP } \\
\text { Semiannual }\end{array}$ & \begin{tabular}{|c|} 
CWA \& \\
INEL ASPEP
\end{tabular} & & W,S & $\mathbf{W , S}$ & $\mathbf{W}, \mathbf{S}$ & & $\overline{W, S}$ & $\mathbf{W}, \mathbf{S}$ & $\mathbf{W , S}$ & & $\mathrm{W}, \mathrm{S}$ & $\mathrm{W}, \mathrm{S}$ & W,S \\
\hline $\begin{array}{l}\text { EMSL-CI WS } \\
\text { Semiannual }\end{array}$ & \begin{tabular}{|c|} 
SDWA \& \\
INEL ASPEP
\end{tabular} & & W & W & $\mathrm{W}$ & & & & & & W & $\mathrm{W}$ & $\mathrm{W}$ \\
\hline $\begin{array}{l}\text { WIPP PDP } \\
\text { Semiannual }\end{array}$ & \begin{tabular}{|c|} 
WIPP \& \\
INEL ASPEP
\end{tabular} & & $\begin{array}{c}\text { G } \\
(\mathrm{HCV})\end{array}$ & & & & $\begin{array}{c}\text { G } \\
(N V G)\end{array}$ & & G & & & & \\
\hline $\begin{array}{l}\text { Corp. of Eng. } \\
\text { PE Program for High } \\
\text { Explosive Residues } \\
\text { As Needed }\end{array}$ & INEL ASPEP & & & & $\begin{array}{c}S, W \\
\text { (HER) }\end{array}$ & & & & $\begin{array}{c}S, W \\
\text { (HER) }\end{array}$ & & & & \\
\hline $\begin{array}{l}\text { RESL MAPEP } \\
\text { Under Development } \\
\text { Semiannual }\end{array}$ & DOE & $\mathrm{W}, \mathrm{S}$ & & $\mathrm{W}, \mathrm{S}$ & & $\mathrm{W}, \mathrm{S}$ & & $\mathrm{W}, \mathrm{S}$ & & $\mathrm{W}, \mathrm{S}$ & & $\mathrm{W}, \mathrm{s}$ & \\
\hline $\begin{array}{c}\text { Commercial PE.Program } \\
\text { As Needed }\end{array}$ & INEL ASPEP & $\mathrm{W}, \mathrm{S}$ & & $\mathrm{W}, \mathrm{S}$ & & $\mathrm{W}, \mathrm{S}$ & & $\mathrm{w}, \mathrm{s}$ & & $\mathrm{W}, \mathrm{S}$ & & $\mathrm{W}, \mathrm{S}$ & \\
\hline
\end{tabular}

Sample Matrix Key: $\quad$ F = Air Filter, $\quad W=$ Water, $\quad S=$ Soil, $\quad B=$ Biota,$\quad G=$ Gas

Special Analyses Key: $\quad$ HER = High Explosive Residue; $\quad$ HCV = High Concentration Volatiles; NVG = Non-VOC Gases; $\quad$ CN $=$ Cyanide 
laboratories that are members of the CLP must participate each quarter as part of their CLP contract. Those laboratories that are not members of the CLP must participate in the QB program semiannually as long as an agreement exists between EPA and DOE allowing such participation. The PE Program Manager is responsible for providing QB samples to non-CLP laboratories.

4. Water Pollution (WP) Performance Evaluation Program: All laboratories that analyze INEL water, soil or waste samples using CWA or RCRA methods must participate in the semiannual WP program sponsored by Environmental Monitoring Systems Laboratory, Cincinnati (EMSL-CI) for all analytes and methods required by INEL programs. (WP participation for RCRA support is an INEL PE program-imposed requirement in order to provide some performance data on the determinative steps of RCRA analyses.)

5. Water Supply (WS) Performance Evaluation Program: All laboratories that analyze INEL samples using SDWA methods must participate in the EMSL-CI's semiannual WS program for all analytes and methods required by INEL programs. Laboratories analyzing SDWA samples must maintain current State of Idaho certification for required analytes.

6. Performance Demonstration Program (PDP) for the Waste Isolation Pilot Plant (WIPP) Experimental Waste Characterization Program: Participation in this program is required for all laboratories supporting headspace gas analyses for WIPP. ${ }^{9}$ Participation in the WIPP PDP ${ }^{10}$ under the auspices of the INEL PE Program is subject to its availability to non-WIPP laboratories. If participation is possible, it will be required semiannually for all laboratories analyzing high concentration VOC gas samples and non-VOC gas samples.

7. Army Corps of Engineers Performance Evaluation Program for Explosives Residue: Active participation in this program, which is administered by the Missouri River Division Office, is required in order for a laboratory to support explosives residue analyses at the INEL.

8. Radiological and Environmental Sciences Laboratory (RESL) Mixed Analyte Performance Evaluation Program (MAPEP): Participation in this DOE-sponsored program, which is still under development, will be required for all laboratories supporting radiochemical and metals analyses of radiologically contaminated water and soil. The frequency of required participation has yet to be determined.

9. Commercial, independently administered PE studies: Participation in these programs [e.g., American Association for Laboratory Accreditation (AALA) or Environmental Resource Associates (ERA)] is required at least semiannually when these programs include analytes/matrices of interest to the INEL that are not addressed by the other existing PE programs (e.g., hexavalent chromium in water). Participation is these programs may also be required as part of corrective actions mandated by the INEL PE Program or as an interim measure until a laboratory can be added by the INEL SMO to the CLP QB program schedule. 
3.1.2.2 INEL-Sponsored Blind PE Materials. All PE materials prepared or used under INEL SMO sponsorship are used as real-time tools to evaluate analytical discipline and methodspecific laboratory performance. Unlike PE materials from existing PE programs, these materials are as closely matched as possible to INEL matrices, analytes of interest, and expected concentration levels. These materials will be submitted blind to the analytical laboratories with batches of field samples so that they are processed simultaneously with the field samples in the laboratory. Costs for these analyses will be absorbed by the INEL project submitting the field samples. INEL-sponsored PE materials may also be used in corrective actions required of the laboratory; in these cases, the laboratory will absorb the cost of the analyses.

All PE materials prepared for the PE Program must meet the following minimum criteria, regardless of the source of the material:

- All materials must be traceable to their source(s)

- Certified concentrations of all material must be traceable to NIST, EPA, U.S. Geological Survey (USGS) or other standard reference materials

- All materials must have a Certificate of Analysis stating the material name, its certified analytes and concentrations, methods used to derive certified values, traceability, lot number, container identification, and date of manufacture

- All materials must be certified for the method whose performance is being evaluated (e.g., total or leachable)

- The matrix, analyte, and concentration ranges must be appropriate for the specific use

- All materials must have homogeneity appropriate for the specific use

- The materials must not contain analyte levels which will cause instrument contamination problems at the analytical laboratories

- Complete chain-of-custody (COC) must be maintained for all PE materials, from time of material preparation through final disposal or expenditure of the material according to the requirements specified in ER PD 5.7, Chain of Custody Records. ${ }^{7}$

There are three types of INEL-sponsored PE materials which may be used as real-time performance evaluation tools: EPA Site Characterized Materials (SCMs); Performance Evaluation Soil Materials (PESMs); and PE materials made from commercially available materials. These tools and their uses are described in the following subsections.

3.1.2.2.1 Site Characterized Materials (SCMs)-SCMs are soil PE materials that were prepared under the direction of EPA Region X from indigenous INEL soils. Separate SCM batches were artificially spiked with metals and SVOCs at concentrations historically found at the 
Rev. 0

INEL. Guidance for the use of SCMs and interpretation of their results is provided by DOE-ID. ${ }^{b}$

3.1.2.2.2 Performance Evaluation Soil Materials (PESMs)-PESMs are materials custom-prepared under the direction of the INEL PE Program Manager. The PESMs consist of indigenous INEL soils that contain radionuclide and metal contaminants (i.e., not artificially spiked). Several PESM batches at various concentration ranges will be prepared through dilution with radiologically clean INEL soils and the addition of contaminants via natural source enhancers (e.g., minerals). By careful selection of source, diluent, and fortification materials, the expected analytes and concentration ranges of actual INEL samples for specific programs may be targeted. These materials require characterization (INEL-sponsored) prior to use as PE materials. ${ }^{11-13}$

Because the particle size of the homogenous PESMs is visually different from that of actual field soil samples, PESMs will be submitted to the laboratories as single-blinds. The frequency of use for these materials required by the INEL PE Program is a minimum of one per project or one per 40 field soil samples of like matrix (for larger projects), whichever is greater. Project managers may request a variance from the real-time $\mathrm{PE}$ sample requirement for very small projects, emergency response, and other special circumstances.

All PESM materials generated by the INEL PE Program will be archived by the INEL SMO for the useful life of the material. Materials with an indefinite shelf life (e.g., non-radioactive elements and long-lived radionuclides) are kept longer than those containing labile analytes (e.g., organic compounds and short-lived radionuclides). The cumulative database of laboratory results for each PESM set will be statistically evaluated to determine when recertification is required for the more labile analyte concentrations.

\subsection{Commercial Performance Evaluation Materials-Private sector} (commercial) sources will be used for real-time PE samples for matrices other than soil (i.e., water, gases, filters). These source materials may be used as stock materials for the preparation of customized PE materials, or used as-is. The purity of these materials must be appropriate for use as a PE material. Likewise, the matrix, analytes, and concentration ranges must be assessed for compatibility with INEL program needs.

The frequency of use for these materials is nominally a minimum of one per project per matrix or one per 40 field samples of like matrix (for larger projects), whichever is greater. Project managers may request a waiver from the real-time PE sample requirement for very small project, emergency response, and other special circumstances.

3.1.2.3 Field Sample Splits. Splits of actual field samples are used as an additional tool to assess real-time analytical discipline and method specific laboratory performance. Field sample splits are prepared in the field by dividing a well-mixed field sample into two representative portions. The two portions are then sent to different laboratories for analysis, and the precision

b. A draft policy has been developed and is awaiting DOE concurrence; letter from C. B. Ozaki, EG\&G Idaho, to A C. Williams, DOE-ID, "Final Policy and Procedures for Use of the Environmental Protection Agency's Idaho National Engineering Laboratory Site Characterized Material Samples," CBO-95-93, July 13, 1993. 
between the resulting data sets evaluated. The cost of these analyses is absorbed by the INEL project collecting the samples.

Because the purpose of these samples is evaluation of laboratory performance, use of collocated samples rather than true splits must be avoided whenever possible so that inhomogeneity between the split portions is minimized. Collocated samples are acceptable only for VOC splits where mixing may cause loss of analytes.

Split field samples are used at the discretion of the PE Program Manager and INEL Project Managers. Use of split samples may be more feasible than real-time PE samples for small scale projects, verification of field screening data, or for unusual matrices for which matrix-matched PE materials are nonexistent or cost-prohibitive. Field sample splits may be used in lieu of commercial PE materials.

3.1.2.4 Field Sample Spikes. Field sample spikes may be used as an additional tool to assess real-time analytical discipline and method specific laboratory performance for effluent water and groundwater analyses. Field sample spikes are prepared by artificially spiking one of the two portions of a split field sample with the analytes of interest. Analyte concentrations added must be documented. Rather than sending the two portions to different laboratories as is done for field sample splits, both portions are sent blind to the same laboratory. Spiked field samples are used at the discretion of the PE Program Manager and INEL Project Managers.

3.1.2.5 Routine Laboratory QC. Routine laboratory QC samples are used to evaluate real-time performance for specific analytical disciplines or methods. The laboratories must analyze all method-required laboratory QC samples at the frequency specified in the methods or in INEL SOWs, TOSs, and SSRs. Results of all QC samples which are not affected by sample matrix (e.g., all except matrix spikes and duplicates) must be within the control limits specified in the methods or in INEL SOWs or TOSs.

One PESM set serves as a known laboratory QC sample (i.e., LCS) source and is provided to the laboratories for use as a quality improvement tool. Laboratories performing metals and radionuclide analysis on INEL soils must analyze this LCS with each analytical batch of INEL soils. The laboratory must recover the target analytes within established acceptance windows. The requirements regarding LCS performance and associated corrective actions detailed in INEL SOWs, TOSs, and SSRs also apply to these LCS PESMs. The LCS PESM may be used in conjunction with or in place of the laboratory's default LCS material. If the laboratory chooses to analyze both the PESM LCS and its default LCS, the laboratory must absorb the cost of analyzing the default LCS (i.e., the INEL will pay for only one LCS).

\subsection{Tools for Evaluation of Data Validator Performance}

Four evaluation tools are used to assess the performance of data validator organizations: on-site audits or desk evaluations, assessment of deliverables, dual validation, and blind test data packages. 
Rev. 0

\subsubsection{Audits or Desk Evaluations}

A combination of on-site audits and desk evaluations is a periodic tool for data validation assessment. Audits and desk evaluations are used to assess performance of the entire validator organization, not individual validators. At a minimum, an annual desk evaluation is required, which includes review of procedures, personnel qualifications, user references, and performance history. On-site audits will be used on an as-needed basis if major problems are identified during the desk evaluations.

\subsubsection{Assessment of Deliverables}

Assessment of deliverables [Limitations and Validation (L\&V) Reports] is a tool for realtime assessment of validator performance. This assessment consists of SMO review of all L\&V Reports, including technical soundness, format and completeness checks, spot-checks against the data package, and verification of compliance with turnaround times and other SOP requirements. ${ }^{14-17}$

\subsubsection{Dual Validation of Data Packages}

Dual validation of data packages is a tool for real-time assessment of validator performance. Five percent of all data packages submitted to data validation service suppliers are simultaneously validated by a different validator (the referee). Referee validation may be done by SMO chemists or other validators having appropriate credentials and good performance history. The L\&V report generated by the data validation service supplier is then compared to the L\&V report produced by the referee validator. Discrepancies between $L \& V$ reports are assessed by SMO chemists or an assigned cognizant professional.

\subsubsection{Blind Test Data Packages}

Blind test data packages are a tool for periodic assessment of validator performance, and consist of copies of previously validated data packages that have no validator marks. These data packages are submitted blind to a validation organization (other than the one which performed the original validation) along with current unvalidated data packages. The resulting L\&V Report is compared to the previous validation report to ensure that all known errors in the data package were identified by the validators and appropriate technical judgements were made. Blind test data packages are submitted semiannually to each validator organization for each analytical discipline which they support. Discrepancies between L\&V reports are assessed by SMO chemists or an assigned cognizant professional. 


\section{PERFORMANCE INDICATORS AND PERFORMANCE ASSESSMENT}

Performance indicators are associated with each of the tools discussed in Section 3. These performance indicators are the basis for qualitative and quantitative assessment of analytical laboratory and data validator performance. Acceptable performance criteria are defined for each performance indicator. Analytical service supplier performance for each indicator is tracked, trended, and compared to the acceptable performance criteria. The frequency of nonconformance to these performance criteria are the basis for evaluating supplier performance.

\subsection{Performance Indicators and Performance Criteria}

Performance indicators and associated acceptable performance criteria are defined for general laboratory performance, specific laboratory analyses, and data validation performance.

\subsubsection{General Laboratory Performance}

General laboratory performance indicators are used to assess laboratory management and operational processes. Areas of assessment are summarized below, and performance indicators and associated acceptable performance criteria are listed in Table 4-1. These parameters are assessed for either the laboratory as a whole, or for specific analytical disciplines and analysis types, as appropriate.

1. Holding Times and Turnaround Times. Holding time (lapsed days from collection to start of sample preparation or analysis) and turnaround time [lapsed days from verified time of sample receipt (VTSR) to receipt of data package by the EG\&G Idaho Field Data Coordinator] performance parameters are tracked for each supplier. Contractually, holding time compliance is critical for legally defensible data. Turnaround time compliance is crucial in meeting regulator-mandated deliverable requirements [e.g., Federal Facility Agreement and Consent Order (FFA/CO)].

2. Completeness and Accuracy of Deliverable. Data package deliverable completeness and accuracy performance parameters are tracked because of their importance in maintaining data defensibility. Resolution of inconsistent, incomplete or inaccurate deliverables is also costly to the INEL due to the number of labor hours required by SMO personnel to resolve the errors. Indicator data are collected from a combination of Level A, B, and C validation feedback.

3. Audits. Laboratory on-site audit or desk evaluation audit results are tracked for each supplier organization. Annual on-site or desk evaluation audits are required to maintain a supplier's SMO approval. Findings during these audits are expected. However, repeated findings (i.e., same finding during multiple audits) indicate a problem with the supplier's quality assurance program, because they should have been corrected after the first occurrence.

4. Responsiveness. Parameters monitoring supplier responsiveness to corrective action requests are tracked because the reflect supplier management commitment to quality and customer service. 
Table 4-1. General laboratory operations performance indicators and acceptable performance criteria.

\begin{tabular}{|c|c|c|c|}
\hline Area of Assessment & Performance Indicator & Performance Criteria & Tracked by: \\
\hline $\begin{array}{l}\text { Holding Time \& } \\
\text { Turnaround Time }\end{array}$ & $\begin{array}{l}\text { Total number of sample delivery groups (SDGs) } \\
\text { having holding time violations per analysis type } \\
\text { - Total number of SDGs with tumaround time } \\
\text { violations }\end{array}$ & $\begin{array}{l}\cdot \text { Zero (0) SDGs with holding } \\
\text { time violations } \\
\text { - Zero (0) SDGs with } \\
\text { turnaround time violations }\end{array}$ & $\begin{array}{l}\text { - Analysis type } \\
\text { - Analysis type }\end{array}$ \\
\hline $\begin{array}{l}\text { Completeness \& Accuracy } \\
\text { of Deliverable }\end{array}$ & $\begin{array}{l}\text { - Number of SDGs for which resubmissions are } \\
\text { requested by the IEDMS DMC due to missing, } \\
\text { incomplete, or inconsistent forms and COCs, during } \\
\text { Level B or Level C validation per analysis type } \\
\text { - Number of SDGs for which resubmissions are } \\
\text { requested by the data validator due to missing, } \\
\text { incomplete, or inconsistent forms, COCs, or raw } \\
\text { data) during Level A validation per analysis type } \\
\text { - Number of SDGs requiring full resubmission per } \\
\text { analysis type } \\
\text { - Number of SDGs in which specified methods were } \\
\text { not used (i.e., method change not approved by SMO) } \\
\text { per analytical discipline }\end{array}$ & $\begin{array}{l}-\leq 1 \text { SDG for which } \\
\text { resubmissions are requested } \\
-\leq 1 \text { SDG for which } \\
\text { resubmissions are requested } \\
\text { - Zero (0) SDGs requiring full } \\
\text { resubmission } \\
\text { Zero (0) SDGs in which } \\
\text { incorrect methods were used }\end{array}$ & $\begin{array}{l}\text { - Analysis type } \\
\text { - Analytical discipline }\end{array}$ \\
\hline Audits & $\begin{array}{l}\text { Number of findings per audit or desk evaluation } \\
\text { repeated from a previous audit or desk evaluation }\end{array}$ & - Zero $(0)$ repeated findings & - Organization \\
\hline Responsiveness & $\begin{array}{l}\text { - Number of corrective action responses not received } \\
\text { within required response time frame } \\
\text { - Number of corrective actions not closed within the } \\
\text { required closure time frame }\end{array}$ & $\begin{array}{l}\text { - Zero (0) corrective action } \\
\text { responses not received within } \\
\text { required response time frame } \\
\\
\text { - } \leq 3 \text { corrective actions not } \\
\text { closed within the required } \\
\text { closure time frame }\end{array}$ & - Organization \\
\hline
\end{tabular}




\subsubsection{Analysis-Specific Laboratory Performance Indicators}

Performance indicators for specific laboratory analyses are listed by analytical discipline in Table 4-2. The listed indicators are applicable for all sample matrices listed in the Applicable Matrices column of the table unless otherwise indicated by a parenthetical clarification.

Biota analyses covered under this program are radionuclide analyses on flora and fauna. Gas analyses covered under this program are VOC and non-VOC gas (e.g., hydrogen, nitrogen, argon, carbon dioxide, carbon monoxide, nitrous oxides) analyses. Indicators for VOC gas analysis are included in the "Organics" analytical discipline, and those for non-VOC gas are included as "Other" under analytical discipline because the analytes do not fit into traditional metals, organics or classical disciplines.

Performance indicators are identified for existing PE programs, INEL-sponsored blind PE samples, and routine laboratory QC. These indicators provide data for overall discipline performance and method and analyte-specific performance. The list may be subject to modification as the Performance Evaluation Program evolves and the usefulness of each indicator is assessed. Performance indicators for analysis of other matrices not specified in this section will be developed as needed.

\subsubsection{Data Validation Performance Indicators}

Areas of data validation supplier performance assessment are summarized below, and specific indicators with their associated acceptable performance criteria are presented in Table 4-3. These parameters are indicators of general organization management and technical performance, and are assessed for the organization as a whole or on an analytical discipline or analysis type basis, as appropriate.

1. Turnaround Time. Turnaround time (lapsed days from data package receipt by validator to receipt of $L \& V$ reports by $E G \& G$ Idaho) is tracked for each supplier. Receipt of $L \& V$ reports within the required time frame is critical in meeting FFA/CO requirements and other project milestones.

2. Deliverable Report Completeness and Accuracy. Deliverable (i.e., L\&V Report) completeness and accuracy performance parameters are tracked for each service supplier. Complete and accurate L\&V Reports are critical because their content impacts project manager decisions on data use. Some L\&V Reports are part of the ER administrative record and are therefore subject to scrutiny by the public or regulator community. Resolution of inconsistent, incomplete or inaccurate deliverables is also costly to the INEL due to the number of labor hours required by SMO personnel to resolve the errors.

3. Deliverable Assessments for Periodic Blinds and Real-Time Dual Validation. Separate indicators are assigned for deliverable assessments for periodic blinds and for real-time dual validation because these tools provide more detailed technical assessments of the data validator performance than does the deliverable completeness and accuracy check listed above. These indicators are chosen to evaluate data validator technical knowledge in their areas of stated expertise. 
Table 4-2. Analysis-specific laboratory performance indicators and acceptable performance criteria.

\begin{tabular}{|c|c|c|c|c|c|c|c|}
\hline \multirow{3}{*}{$\begin{array}{l}\text { Analytical } \\
\text { discipline }\end{array}$} & \multirow[b]{3}{*}{ Applicable matrices } & \multicolumn{4}{|c|}{ PE Programs and INEL-Sponsoned Blind PE Sanmples } & \multirow{2}{*}{\multicolumn{2}{|c|}{$\begin{array}{c}\text { Routine Luboratóry QC } \\
\text { (Aralyro- and Mathod-Specific) }\end{array}$}} \\
\hline & & \multicolumn{2}{|c|}{ Overall Performances (Analytical Disciplise or Analyois Type) } & \multicolumn{2}{|c|}{ Analyior and Method-Specifio Performansos } & & \\
\hline & & Performanoo Indications & Acoeplable Performenses Criceria & Performancos Ladicalora & Accephablo Performenoo Criteria & Performentoe Indicators & Acepplable Performanos Criteria \\
\hline Rediochemistry & W, S, F, B & $\begin{array}{l}\text { Number of analytes misqualificod } \\
\text { (i.o., not correctly identifiod) per } \\
\mathrm{PE} \text { samplo } \\
\text { Number of analytes misquantified } \\
\text { per PE sample }\end{array}$ & $\begin{array}{l}\leq 1 \text { per PE samplo } \\
-\leq 10 \% \text { of toal number of } \\
\text { requestod aralytes per PE samplo }\end{array}$ & O Recovery of Analyto & $\begin{array}{l}\text { Within definod acopplatico } \\
\text { limits for PE samplo }\end{array}$ & 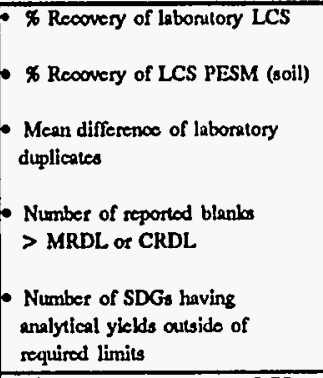 & $\begin{array}{l}\text { - Wilhin method/SOW requirements } \\
\text { - Within cetablishod control limits } \\
\text { - Within melhod/SOW requirements } \\
\leq 1 \\
-\leq 1 \mathrm{SDG} \text { affecod by any } \\
\text { outl.of-control analytical yicld }\end{array}$ \\
\hline Metals & W, S, F & $\begin{array}{l}\text { CLP QB score, when applicable } \\
\text { Nurnber of anaiytes misquatificod } \\
\text { per PE sample } \\
\text { - Number of analytes misquantifiod } \\
\text { per PE oamplo }\end{array}$ & $\begin{array}{l}\text { CLP QB Score } \geq 75 \\
0 \leq 1 \text { per PE samplo } \\
\leq 10 \% \text { of toul murber of } \\
\text { requested analyres per PE sample }\end{array}$ & - A Recovery of Analyto & $\begin{array}{l}\text { Wihtin definod acceptanco } \\
\text { limile for PE sample }\end{array}$ & 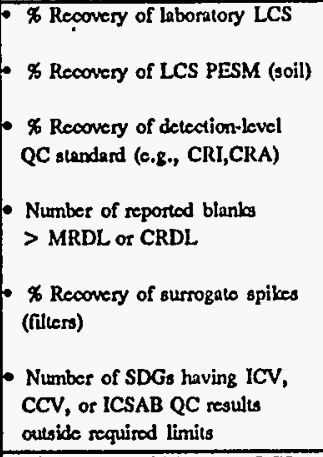 & $\begin{array}{l}\text { - Within method/SOW requirements } \\
\text { - Within establisbed control limits } \\
\pm S 0 \% \text { of true value } \\
\leq 1 \\
\text { - Within method/sOW requirements } \\
\text { - } 1 \mathrm{SDG} \text { affectod by any out-of- } \\
\text { control ICV, CCV, or ICSAB }\end{array}$ \\
\hline Organics & $\mathbf{W}, \mathbf{S}, \mathbf{G}$ & $\begin{array}{l}\text { CLP QB scone, when applicable } \\
\text { Number of analyes misqualifiod } \\
\text { per PE sample } \\
\text { Nurnber of annalyles misquantificd } \\
\text { per PE sample }\end{array}$ & $\begin{array}{l}\text { CLP QB Scoro } \geq 75 \\
\leq 1 \text { per PE sample } \\
010 \% \text { of folal number of } \\
\text { sequestod analytes per PE semple }\end{array}$ & $\begin{array}{l}\text { \% Recovery of Analyce } \\
\text { RPD betwoen fiedd sample } \\
\text { splits (gas matrix eamples } \\
\text { only) }\end{array}$ & $\begin{array}{l}\text { Within defined acoeptance } \\
\text { limils for PE sample } \\
\text { RPD } \leq \text { (Method lab duplicate } \\
\text { RPD control limit + 50\%) }\end{array}$ & 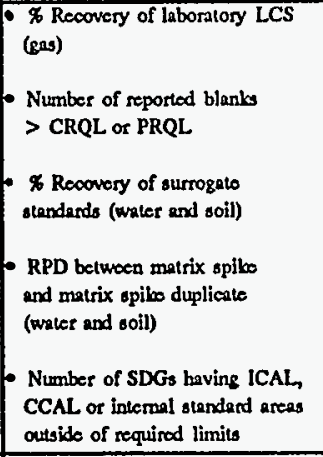 & $\begin{array}{l}\text { - Within method/SOW requirements } \\
\text { - Within metbod/SOW requirements } \\
\text { - Within method/SOW requirement } \\
\text { - } \leq 1 \text { SDG affected by any at-of- } \\
\text { control ICAL, CCAL, or intemal } \\
\text { standard area }\end{array}$ \\
\hline Cirssical & w, s & $\begin{array}{l}\text { Number of analyntes misqualified } \\
\text { per PE sample } \\
\text { Number of aralytyes misquantifiod } \\
\text { per PE sample }\end{array}$ & $\begin{array}{l}\leq 1 \text { per PE samplo } \\
\text { - } \leq 10 x \text { of todal number of } \\
\text { requestod analyles per PE sample }\end{array}$ & - \% Recovery of analyro & $\begin{array}{l}\text { Within defined acceptansos } \\
\text { limits for PE samplo }\end{array}$ & $\begin{array}{l}\text { o Recovery of laboratory LCS } \\
\text { Number of reported blanles } \\
>\text { CRDL or MRDL }\end{array}$ & $\begin{array}{l}\text { - Within method/SOW requirements } \\
-\leq 1\end{array}$ \\
\hline Oher: & G & $\begin{array}{l}\text { Overall PDP Score } \\
\text { - Number of analyres misqualified } \\
\text { per PE semple } \\
\text { - Number of anelytyes misquantifiod } \\
\text { per PE semple }\end{array}$ & $\begin{array}{l}\text { Critical Terget Combound, (CTC) } \\
\text { score } \geq 0.95 \text { \& Target Compound } \\
\text { (TC) scoro } \geq 0.75 \\
\leq 1 \text { per PE sample } \\
\leq 10 \% \text { of todal number of } \\
\text { requested anaistes per PE sample }\end{array}$ & - Fo Recovery of anaigro & $\begin{array}{l}\text { Wilhin defined aceptanoe } \\
\text { limits for PE sumple }\end{array}$ & - T Recovery of laboratory LCS & - Wilhin method/SOW requirements \\
\hline
\end{tabular}

क्ष.

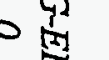


Table 4-3. Data validation performance indicators and acceptable performance criteria.

\begin{tabular}{|c|c|c|c|}
\hline AREA OF ASSESSMENT & PERFORMANCE INDICATORS & PERFORMANCE CRITERIA & TRACKED BY: \\
\hline Turnaround Times & $\begin{array}{l}\text { Total number of turnaround time violations per } \\
\text { analytical discipline }\end{array}$ & $\begin{array}{l}\text { - Zero }(0) \text { L\&V reports with } \\
\text { turnaround time violations }\end{array}$ & $\begin{array}{l}\text { Analytical } \\
\text { discipline }\end{array}$ \\
\hline $\begin{array}{l}\text { Deliverable Completeness \& } \\
\text { Accuracy }\end{array}$ & $\begin{array}{l}\text { Total number of L\&V Reports for which } \\
\text { resubmissions are requested by the SMO per analysis } \\
\text { type }\end{array}$ & $\begin{array}{l}-\leq 1 \mathrm{L \& V} \text { for which } \\
\text { resubmissions are requested }\end{array}$ & - Analysis type \\
\hline $\begin{array}{l}\text { Deliverable } \\
\text { Assessment of Periodic } \\
\text { Blinds and Real-Time Dual } \\
\text { Validation }\end{array}$ & $\begin{array}{l}\text { - Number of problems associated with the data } \\
\text { package identified by the data validator as a } \\
\text { percentage of the total number of problems identified } \\
\text { by referee validation per analysis type } \\
\text { - Number of L\&V Reports affected by errors evaluating } \\
\text { the following critical parameters: COC, rejected data } \\
\text { points, and incorrectly assigned data qualifier flags } \\
\text { (i.e., those assigned which should not have been } \\
\text { assigned, and those which were not assigned when } \\
\text { they should have been) per analysis type }\end{array}$ & $\begin{array}{l}-95 \%-100 \% \text { of problems } \\
\text { identified by referee validation } \\
-\leq 1 \mathrm{~L} \& V \text { Report affected by } \\
\text { critical parameter errors }\end{array}$ & $\begin{array}{l}\text { Analysis type } \\
\text { - Analysis type }\end{array}$ \\
\hline Audits & $\begin{array}{l}\text { Number of findings per audit or desk evaluation } \\
\text { repeated from a previous audit or desk evaluation }\end{array}$ & - Zero $(0)$ repeated findings & - Organization \\
\hline Responsiveness & $\begin{array}{l}\text { Number of corrective action responses not received } \\
\text { within required response time frame } \\
\text { - Number of corrective actions not closed within the } \\
\text { required closure time frame }\end{array}$ & $\begin{array}{l}\text { Zero (0) corrective action } \\
\text { responses not received within } \\
\text { required response time frame } \\
\text { - } \leq 3 \text { corrective actions not } \\
\text { closed within the requried } \\
\text { closure time frame }\end{array}$ & $\begin{array}{l}\text { Organization } \\
\text { - Organization }\end{array}$ \\
\hline
\end{tabular}


Rev. 0

4. Audits. Data validator desk evaluation or on-site audit results are tracked for each supplier organization. Annual desk evaluation or on-site audits are required to maintain a supplier's SMO approval. Findings during these audits are expected. However, repeated findings (i.e., same finding during multiple audits) indicate a problem with the supplier's quality assurance program, because they should have been corrected after the first occurrence.

5. Responsiveness. Parameters monitoring supplier responsiveness to corrective action requests are tracked because the reflect supplier management commitment to quality and customer service.

\subsection{Indicator Assessment Process}

Assessment of performance for analytical service suppliers is based on the performance indicators and associated acceptable performance criteria defined in Section 4.1.

\subsubsection{Indicator Tracking and Trending}

The PE Program Office tracks and trends performance indicator results and compliance with the associated acceptable performance criteria for each analytical service supplier. Tracking and trending tools used include but are not limited to statistical analysis, control charts, and frequency histograms. Specific implementing details of the tracking and trending process shall be documented in SOPs.

Ancillary data may be tracked with some of the performance indicators to provide the PE Program Office with a better perspective of service supplier performance. For example, the performance indicator for laboratory holding time is the total number of SDGs having holding time violations per analysis type, and the acceptable performance criteria for this indicator is zero SDGs with holding time violations. Ancillary data tracked with this indicator might include the number of samples, number of days by which the holding time was exceeded, and the analytical method.

During tracking and trending of performance indicator results, the PE Program Office may note trends in conforming data that indicate that the potential exists for future nonconformance to acceptable performance criteria (e.g., analyte recovery steadily dropping over time). When found, the PE Program Office notifies the supplier of these Trend Conditions (TCs), using a form like that shown in Figure 4-1. Because TCs have not yet resulted in a nonconformance to acceptable performance criteria, any action taken in response to the notification is at the sole discretion of the supplier.

\subsubsection{Supplier Nonconformances}

Failure to meet the acceptable performance criteria for any performance indicator constitutes a supplier nonconformance (SNC). The PE Program Office notifies the supplier (see Figure 4-1 for an example of a notification form) of the SNC within two to three working days of discovery. Written supplier response to all SNCs is required. Corrective action in response to the initial occurrence of an SNC is at the discretion of the supplier, but is strongly recommended. The initial occurrence of a SNC is considered to be a warning, and a recurrence of the SNC for 


\section{SUPPLER NONCONFORMANCE (SNC) SUMMARY SUPPLER TREND CONDITION (TC) SUMMARY}

\begin{tabular}{|c|c|}
\hline 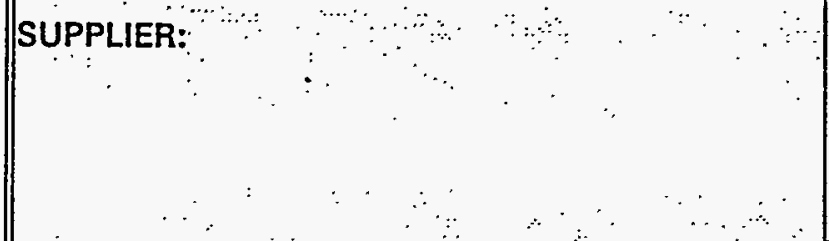 & $\begin{array}{l}\therefore \text { 口 SNC } \\
\text { SNC/TC Number: } \\
\text { Status Change Associated? Yes or No } \\
\text { Status Change \#: } \\
\square \text { Probation } \square \text { Suspension } \square \text { Termination }\end{array}$ \\
\hline a Laboratory a Validator & Date Initiated: \\
\hline Affected TOS/SS & SR\#: \\
\hline Performance Indicator: & \\
\hline |Requirement: & \\
\hline Description of Nonconformance/TC: & \\
\hline Originator: & PE Program Manager: \\
\hline COMPLETE REMAINING SECTIONS FOF & R SUPPLIER NONCONFORMANCE ONLY \\
\hline 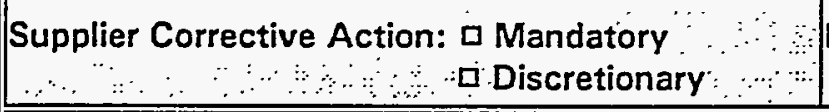 & 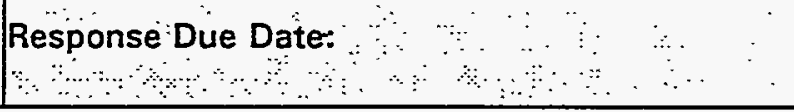 \\
\hline $\begin{array}{l}\text { Date Supplier Response Recieved: } \\
\text { Supplier Response Reference: }\end{array}$ & Supplier Disposition: \\
\hline Brief Summary of Supplier Response: & $\begin{array}{c}\text { Did/Will Supplier Perform Corrective Action? } \\
\text { Yes or No } \\
\text { If Yes, anticipate correction date: }\end{array}$ \\
\hline & $\begin{array}{l}\text { Is supplier response adequate? Yes or No } \\
\text { If No, why not? }\end{array}$ \\
\hline Cause of Nonconformance: & $\begin{array}{ll}\text { PE Program Office: } & \text { Date: } \\
\text { PE Program QAO: } & \text { Date: }\end{array}$ \\
\hline Date Supplier Corrective Action Completed: & 口 SNC Closed Date: \\
\hline PE Program Office: & PE Program QAO: \\
\hline
\end{tabular}

Figure 4-1. Example of Supplier Nonconformance/Trend Condition Notification Form. 
Rev. 0

the same indicator has an adverse impact on the supplier's performance status (see Section 5 , Performance Status).

Multiple SNCs on an indicator may occur sequentially or simultaneously. Two successive failures to meet acceptable performance criteria will result in two SNCs, as will two concurrent failures to meet acceptable performance criteria. For example, two SDGS analyzed together that are affected by holding time violations has the same effect as two SDGs affected by holding time violations but analyzed several weeks apart; two SNCs are incurred.

PE Program Office and supplier actions in response to initial and multiple occurrences of SNCs are discussed in Section 5. The supplier QA officer is the point of contact for interaction with the PE Program Office on SNCs. All SNCs and any. associated corrective actions are reviewed by the PE Program Manager and QAO.

\subsubsection{Variances}

In certain limited instances, the PE Program may waive the acceptable performance criteria for an indicator. This waiving of requirements constitutes a Variance. If circumstances arise that would cause a supplier to incur an SNC through no fault of their own, a variance will be granted so that the occurrence is not counted against the service supplier. An example of such a circumstance would be the receipt of samples by a laboratory after expiration of the holding time, whether the fault lies with EG\&G Idaho or the sample shipper. Figure 4-2 provides an example of a Variance transmittal form.

A Supplier may request a variance on technical grounds from the PE Program Office in cases where waiving of a requirement has either no effect on the deliverable or improved the quality of the deliverable. For example, if after receipt and examination of a sample, the laboratory determines that the required method will not work for that sample, the laboratory may request a variance to use a different method.

Supplier requests for variance must have a technical justification, and should not be made for the sake of convenience. The decision to grant or deny a supplier-requested variance is the sole discretion of the PE Program Office. A variance must be granted prior to any knowing violation of acceptable performance criteria by the supplier; a variance cannot be issued after the occurrence. Service suppliers must not anticipate the issuance of a variance. Any work performed in violation of acceptable performance criteria before a variance is officially issued (in writing) will incur a SNC.

All variances must be approved by the $P E$ Program Manager and reviewed by the $P E$ Program QAO. Depending on the nature of the variance, project managers and EG\&G procurement will be involved in the approval process. 


\section{RECORD OF VARIANCE}

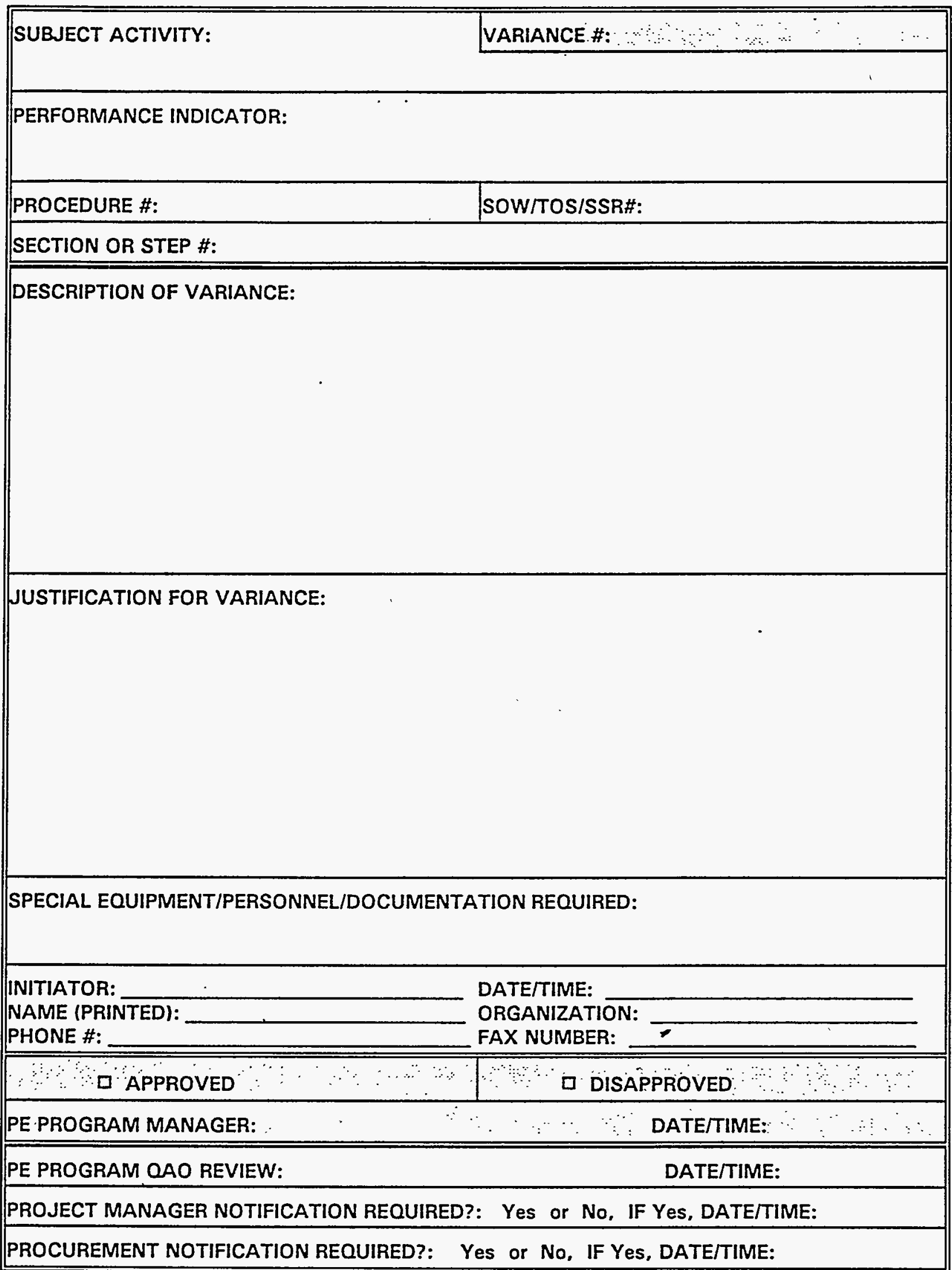

Figure 4-2. Example of Record of Variance Form. 


\section{PERFORMANCE STATUS}

The current performance status of each SMO-approved analytical service supplier is determined from results of performance indicator assessments. Status records are maintained for analytical laboratory general operations and for analytes, methods, analysis types, and analytical disciplines as appropriate for the laboratory's support to the SMO. Status of data validation suppliers is determined for analysis types, analytical disciplines and overall performance. Analytical service supplier nonconformances (SNCs) occur when performance indicators fail to meet the acceptable performance criteria defined in Section 4. The nature and number of these nonconformances determine the performance status earned by the supplier.

\subsection{Performance Status Change}

The performance status of SMO-approved suppliers is divided into one of the following categories: satisfactory, probation, suspension, and termination. These categories are discussed in detail in Section 5.2. Figure 5-1 is a schematic representation of the relationship between the performance status classifications and the potential pathways for changes in performance status. This section discusses supplier performance status determination, grounds for changing performance status, and requirements for resolving performance problems.

Tables 5-1 and 5-2 outline the grounds for changing supplier performance status for analytical laboratories and data validators, respectively. The tables are organized to reflect the scope and severity of a performance status change. Progression from left to right across the tables reflects increasingly pervasive impacts due to a performance problem. The severity of the performance problem increases from top to bottom of the tables. An example of increasing pervasiveness is nonconformances affecting several analytes, which in turn impact an entire multianalyte method, and which ultimately, if unresolved, could affect the entire analytical discipline within a laboratory. The severity of a performance problem increases with multiple occurrences or unresolved corrective actions in the preceding categories. Repeated or unresolved performance problems will roll a supplier's status further toward the bottom right of the tables.

The performance status of a supplier may be changed for part or all of their organization. Individual functions within the supplier organization may be affected independent of one another. The manner in which the performance indicators are tracked dictates the entry point into the status change tables. For analytical laboratories, performance status changes may be invoked on an analyte, method or analytical discipline basis, or for the entire laboratory. In some cases, laboratory performance status changes may also be invoked for certain analysis types within the discipline (e.g., VOC, SVOC, GFAAS methods), where the performance status change effects more than one method but not the entire discipline. The performance status of data validators may be changed on an analytical type or analytical discipline basis as well as for the entire organization. All changes in supplier performance status are made with EG\&G Procurement concurrence; changes involving Stop Work orders (i.e., suspension and termination) are made by EG\&G Procurement at the request of the PE Program Office. An example of a Status Change Notification form is provided in Figure 5-2. 


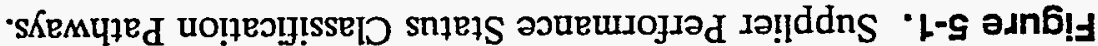

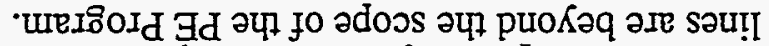

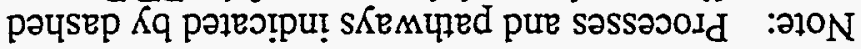
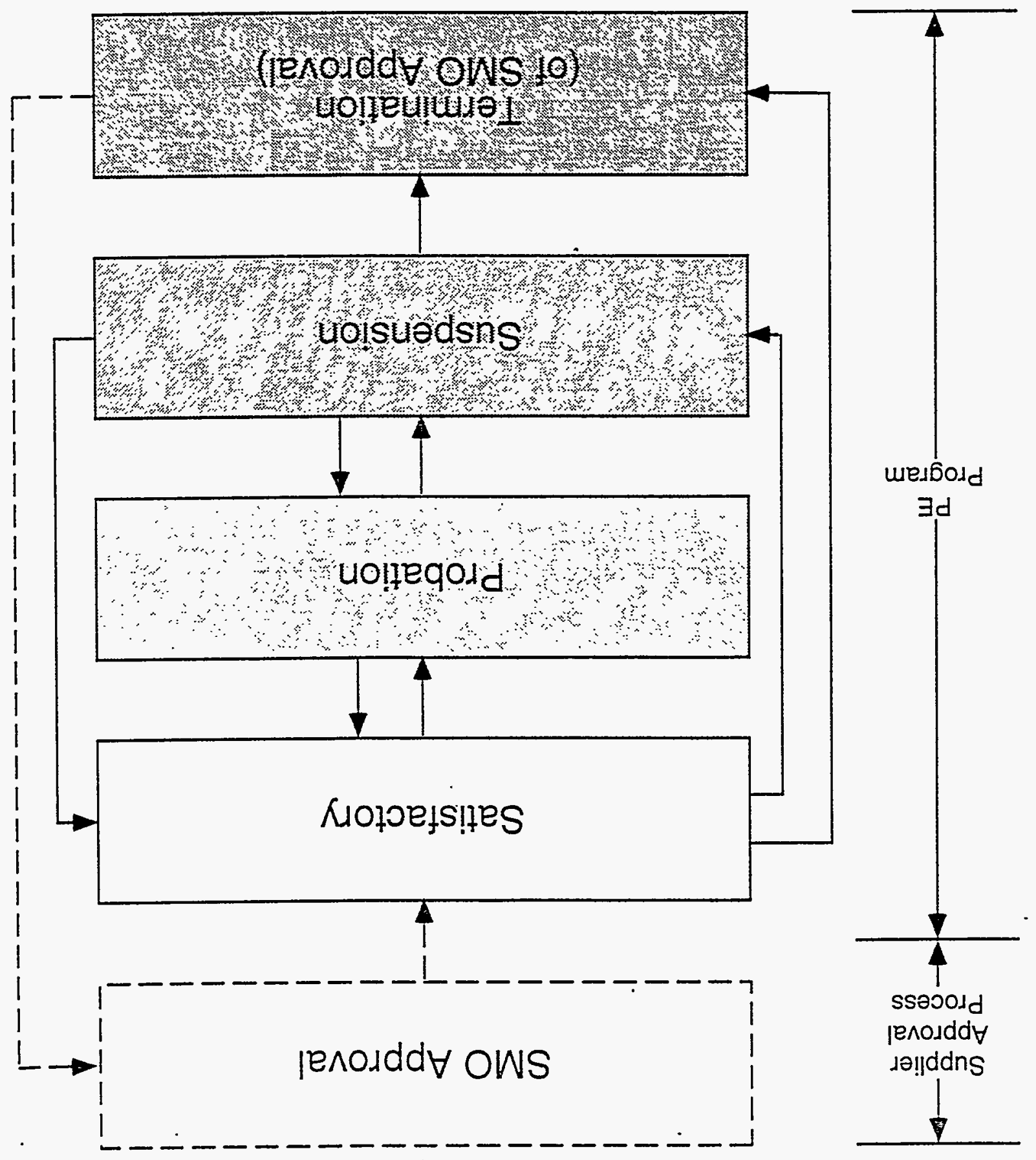
Table 5-1. Grounds for change in laboratory performance status.

\begin{tabular}{|c|c|c|c|c|c|c|}
\hline \multirow{2}{*}{\multicolumn{2}{|c|}{ Performance Status }} & \multicolumn{5}{|c|}{ Scope of Impact } \\
\hline & & $\begin{array}{l}\text { Single Analyte Method or } \\
\text { Single Analyte from Multiple-Analyte } \\
\text { Method }\end{array}$ & Multiple-Analyte Method & Analysis Type & Analytical Discipline & $\begin{array}{c}\text { Analytical Support Supplier } \\
\text { Organization }\end{array}$ \\
\hline \multirow[t]{2}{*}{ Satisfactory } & $\overline{T C C}$ & $\begin{array}{l}\text { - Negative trend in indicałors } \\
\text { - PE score in warning range }\end{array}$ & $\begin{array}{l}\text { - Adverse trend in indicators } \\
\text { - } \mathrm{PE} \text { score in warning range }\end{array}$ & - Adverse trend in indicators & Adverse trend in indicators & Adverse trend in indicators \\
\hline & $\widehat{\text { SNC }}$ & $\begin{array}{l}\text { Failure to meet performance } \\
\text { criteria for any specific } \\
\text { laboratory analysis indicator } \\
\text { tracked by analyte or method }\end{array}$ & $\begin{array}{l}\text { Failure to mect performance } \\
\text { criteria for any specific } \\
\text { laboratory analysis indicator } \\
\text { tracked by method }\end{array}$ & $\begin{array}{l}\text { Failure to meet assessment } \\
\text { criteria for any general } \\
\text { performance indicator tracked } \\
\text { by analysis type }\end{array}$ & $\begin{array}{l}\text { Failure to meet performance } \\
\text { criteria for any general } \\
\text { performance indicator } \\
\text { tracked by discipline }\end{array}$ & $\begin{array}{l}\text { Failure to mect performance } \\
\text { criteria for any general } \\
\text { performance indicator } \\
\text { tracked by organization }\end{array}$ \\
\hline Probation & & $\begin{array}{l}\text { SNC on } 2 \text { or more indicators } \\
\text { - } 2 \text { SNCs on a single indicator } \\
\text { - SNC on an indicator which was } \\
\text { the cause of previous probation } \\
\text { or suspension }\end{array}$ & $\begin{array}{l}2 \text { or more probations } \\
\text { affecting a single analyte } \\
\text { - SNCs on multiple analytes } \\
\text { - SNC within a method which } \\
\text { has had a previous probation } \\
\text { or suspension }\end{array}$ & $\begin{array}{l}\text { Probation on multiple } \\
\text { methods within the analysis } \\
\text { type } \\
\text { SNCs in } 2 \text { or more single- } \\
\text { analyte methods within the } \\
\text { analysis type } \\
2 \text { SNCs on a single general } \\
\text { indicator tracked by analysis } \\
\text { type } \\
\text { SNCs on muliple general } \\
\text { indicators tracked by analysis } \\
\text { type } \\
\text { SNC on a general indicator } \\
\text { which was the cause of } \\
\text { previous probation or } \\
\text { suspension }\end{array}$ & $\begin{array}{l}\text { Probations in multiple } \\
\text { analysis types within a } \\
\text { discipline } \\
\text { - SNCs on a single general } \\
\text { indicator tracked by } \\
\text { analytical discipline } \\
\text { - SNCs on muliple general } \\
\text { indicators tracked by } \\
\text { analytical discipline } \\
\text { SNC on a general indicator } \\
\text { which was the cause of } \\
\text { previous probation or } \\
\text { suspension } \\
\text { SNC on CLP QB Score }\end{array}$ & $\begin{array}{l}\text { Probation in } 2 \text { or more } \\
\text { disciplines } \\
\text { Multiple SNCs on a general } \\
\text { performance indicator } \\
\text { tracked by organization } \\
\text { SNC on multiple general } \\
\text { performance indicators } \\
\text { tracked by organization } \\
\text { SNC on a gencral indicator } \\
\text { which was the cause of } \\
\text { previous probation or } \\
\text { suspension }\end{array}$ \\
\hline Suspension & & $\begin{array}{l}\text { Failure to close probation CA } \\
\text { within allowed response time } \\
\text { frame } \\
2 \text { open probation corrective } \\
\text { actions on a single indicator } \\
\text { - Open probation corrective } \\
\text { actions on } 2 \text { or more indicators }\end{array}$ & $\begin{array}{l}\text { Failure to close CA for } \\
\text { mutilple-analyte method } \\
\text { probation within allowed time } \\
\text { frame } \\
\text { - } 2 \text { open probations affecting } \\
\text { the method } \\
\text { - Suspension of } 1 \text { or more } \\
\text { analytes }\end{array}$ & $\begin{array}{l}\text { Failure to close analysis type } \\
\text { probation CA within allowed } \\
\text { time frame } \\
2 \text { open analysis type } \\
\text { probation corrective actions } \\
\text { - Multiple method suspensions } \\
\text { within analysis type }\end{array}$ & $\begin{array}{l}\text { Failure to resolve analytical } \\
\text { discipline probation CA } \\
\text { within allowed time frame } \\
2 \text { open analytical discipline } \\
\text { probations } \\
\text { - Suspension of multiple } \\
\text { analysis types within a } \\
\text { discipline } \\
\text { Sequential SNCs for any } \\
\text { WS PE sample analyte } \\
\text { recovery indicator }\end{array}$ & $\begin{array}{l}\text { Failure to close CA for } \\
\text { supplier organization } \\
\text { probation within allowed time } \\
\text { frame } \\
2 \text { open supplier probation } \\
\text { corrective actions } \\
\text { Suspension in } 2 \text { or more } \\
\text { disciplines }\end{array}$ \\
\hline $\begin{array}{l}\text { Termination of } \\
\text { Approval }\end{array}$ & & $\begin{array}{l}\text { Failure to resolve suspension } \\
\text { CA within negotiated time frame } \\
\text { - } 3 \text { suspensions on a single } \\
\text { indicator }\end{array}$ & $\begin{array}{l}\text { Failure to close method } \\
\text { suspension CA within } \\
\text { allowed time frame } \\
\text { - } 3 \text { method suspensions } \\
\text { - Termination of any analyte }\end{array}$ & $\begin{array}{l}\text { Failure to close analysis type } \\
\text { suspension CA within allowed } \\
\text { time frame } \\
3 \text { analysis type suspensions } \\
\text { Termination of multiple methods } \\
\text { within the analysis type }\end{array}$ & $\begin{array}{l}\text { Failure to close analytical } \\
\text { discipline suspension CA } \\
\text { within allowed time frame } \\
\text { - } 3 \text { analytical discipline } \\
\text { suspensions } \\
\text { - Termination for multiple } \\
\text { analysis types per discipline }\end{array}$ & $\begin{array}{l}\text { Falsification of laboratory } \\
\text { records or data } \\
\text { - Failure to close CA from } \\
\text { supplier organization } \\
\text { suspension within allowed } \\
\text { time frame } \\
\text { - Termination of } 2 \text { or more } \\
\text { disciplines }\end{array}$ \\
\hline
\end{tabular}

CAQ = Condition Adverse to Quality; $\quad$ CA $=$ Corrective Action; $\quad$ SNC $=$ Supplier Nonconformance 
Table 5-2. Grounds for change in data validator performance status.

\begin{tabular}{|c|c|c|c|c|}
\hline \multirow{2}{*}{\multicolumn{2}{|c|}{ Performance Status }} & \multicolumn{3}{|c|}{ Scope of Impact } \\
\hline & & Analysis Type & Analytical Discipline & Analytical Support Supplicr Organization \\
\hline \multirow[t]{2}{*}{ Satisfactory } & TC & - Adverse trend in indicators & - Adverse trend in indicators & - Adverse trend in indicators \\
\hline & SNC & $\begin{array}{l}\text { Failure to meet performance criteria } \\
\text { for any indicator tracked by analysis } \\
\text { type }\end{array}$ & $\begin{array}{l}\text { - Failure to meet performance criteria } \\
\text { for any indicator tracked by analytical } \\
\text { discipline }\end{array}$ & $\begin{array}{l}\text { - Failure to meet assessment criteria for } \\
\text { any indicator tracked by organization }\end{array}$ \\
\hline Probation & & $\begin{array}{l}\text { 2 SNCs on a single indicator } \\
\text { - SNCs on multiple indicators within } \\
\text { the analysis type } \\
\text { - SNC on an indicator which was the } \\
\text { cause of previous probation or } \\
\text { suspension }\end{array}$ & $\begin{array}{l}\text { - } 2 \text { SNCs on a single indicator (tracked } \\
\text { by discipline) } \\
\text { - SNCs on mulitiple indicators tracked } \\
\text { by discipline } \\
\text { - } 2 \text { or analysis type probations within } \\
\text { the discipline } \\
\text { - SNC on an indicator (tracked by } \\
\text { discipline) which was the cause of } \\
\text { previous probation or suspension }\end{array}$ & $\begin{array}{l}\text { - } 2 \text { SNCs on a single indicator (tracked } \\
\text { by organization) } \\
\text { - SNCs on mulitiple indicators tracked } \\
\text { by organization } \\
\text { - Probation in multiple analytical } \\
\text { disciplines } \\
\text { - SNC on an indicator (tracked by } \\
\text { organization) which was the cause of } \\
\text { previous probation or suspension }\end{array}$ \\
\hline Suspension & & $\begin{array}{l}\text { - Failure to close probation CA within } \\
\text { allowed time frame } \\
\text { - } 2 \text { open probation CAs within the } \\
\text { analysis type }\end{array}$ & $\begin{array}{l}\text { - Failure to close CAs for discipline } \\
\text { probation within the allowed time } \\
\text { frame } \\
\text { - } 2 \text { open probation CAs within for } \\
\text { indicators tracked by discipline } \\
\text { - Suspension of multiple analysis types } \\
\text { within the discipline }\end{array}$ & $\begin{array}{l}\text { - Failure to close CA for supplier } \\
\text { organization probation within the } \\
\text { allowe time frame } \\
\text { - } 2 \text { open probation CAs within for } \\
\text { indicators tracked by organization } \\
\text { - Suspension of multiple disciplines }\end{array}$ \\
\hline Termination of Approval & & $\begin{array}{l}\text { - Failure to close suspension CA } \\
\text { within allowed time frame } \\
\text { - } 3 \text { suspensions within the analysis } \\
\text { type }\end{array}$ & $\begin{array}{l}\text { - Failure to close CA due to discipline } \\
\text { suspension within the allowed time } \\
\text { frame } \\
\text { - } 3 \text { suspensions for an indicator tracked } \\
\text { by analytical discipline } \\
\text { - Termination of multiple analysis types } \\
\text { within the discipline }\end{array}$ & $\begin{array}{l}\text { - Falsification of L\&V reports } \\
\text { - Failure to close CA for supplier } \\
\text { organization suspension within allowed } \\
\text { time frame } \\
\text { - } 3 \text { suspensions for an indicator tracked } \\
\text { by organization } \\
\text { - Termination multiple disciplines }\end{array}$ \\
\hline
\end{tabular}


INEL ANALYTICAL SERVICES PERFORMANCE EVALUATION PROGRAM Rev. 0

NOTIFICATION OF PERFORMANCE STATUS CHANGE

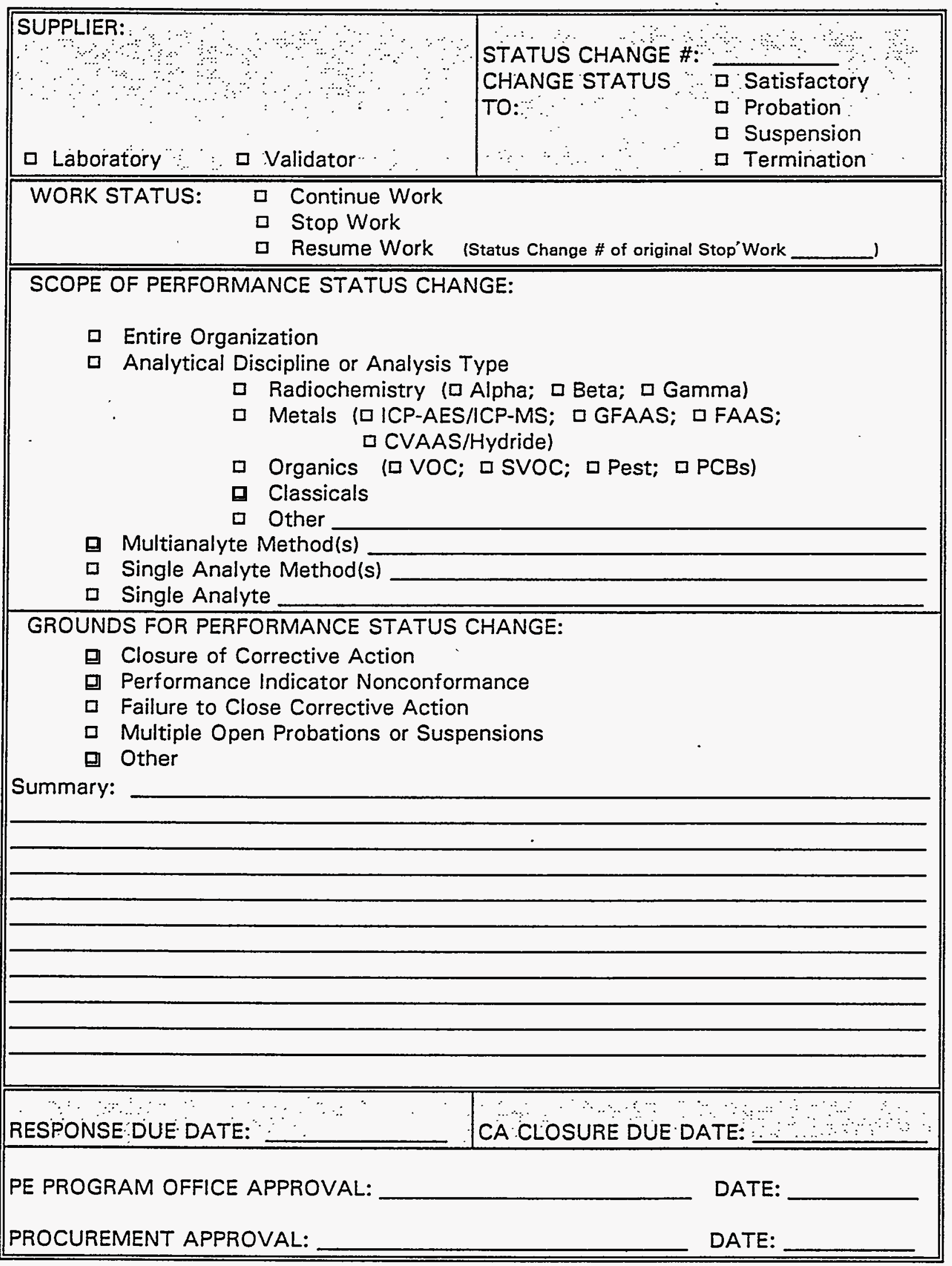

Figure 5-2. Example of Notification of Performance Status Change Form. 
Rev. 0

\subsection{Performance Status Classifications}

Table 5-3 summarizes actions required of the PE Program Office, EG\&G Procurement, and the supplier to change supplier performance status and resolve performance problems. These processes are discussed in the following subsections.

\subsubsection{Satisfactory Performance}

Supplier performance status is satisfactory if it meets the requirements of the INEL PE Program and if none of the grounds for probation, suspension, or termination listed in Tables 5-1 or 5-2 exist. The supplier is deemed capable of supplying a product which will meet the requirements of INEL projects, and the supplier's SMO approval is unqualified.

SNCs may occur without affecting the supplier's performance status. The PE Program Office notifies the supplier of SNCs by FAX within three working days of discovery. As part of the notification, the PE Program Office establishes a time period within which the supplier must respond to the SNC. Written supplier response to SNCs which do not invoke a change in performance status is required, and consists of dispositioning the $\mathrm{SNC}$, determining if corrective action is necessary to prevent recurrence, and providing this information to the PE Program Office. Identification of appropriate corrective action strategies and their implementation in response to an SNC is at the discretion of the supplier. If, after three months of active support (i.e., months in which the supplier performs work for the SMO), there are no further recurrences of an SNC that did not contribute to a status change, the SNC tally is set back to zero for purposes of determining status change.

The PE project office notifies (i.e., counsels) the supplier of any Trend Conditions observed during performance indicator assessment. This notification will be made, in writing, from the PE program manager or designee to the supplier QA officer, on an as needed basis. Because these TCs have not yet resulted in an SNC, any action resulting from this notification is at the discretion of the supplier.

\subsubsection{Supplier Probation}

If supplier performance does not meet INEL PE program requirements in one or more areas which may cause adverse impact on the quality of their product (i.e., multiple SNCs), the supplier is placed on probation. The supplier's SMO approval is qualified and corrective action to address the cause(s) of the probationary status is mandatory.

Grounds for downgrading supplier status from satisfactory to probation are listed in Tables 5-1 and 5-2. With the concurrence of EG\&G Procurement, the PE Program Office notifies the supplier of probationary status by FAX. Probation notices must identify the scope of the probation (e.g., analyte, method, analytical discipline, or entire supplier affected by the probation), the grounds for invoking probation, the time period granted the supplier for response, and the required closure date (if applicable) for corrective action. Probation becomes effective when the PE Program Office makes the notification to the supplier.

The amount of time allowed for supplier response and corrective action closure are determined by the PE Program office. The amount of time allowed for response depends upon 
Table 5-3. Supplier performance status resolution.

\begin{tabular}{|c|c|c|c|c|c|}
\hline \multirow[b]{2}{*}{ Condition } & \multirow{2}{*}{$\begin{array}{l}\text { Impact on } \\
\text { Data Quality }\end{array}$} & \multirow{2}{*}{$\begin{array}{l}\text { SMO Approval } \\
\text { Status }\end{array}$} & \multicolumn{3}{|c|}{ Actions } \\
\hline & & & PE Program Office & EG\&G Procurement & Supplier \\
\hline Trend Condition & None & $\begin{array}{l}\text { Satisfactory } \\
\text { (Not Affected) }\end{array}$ & $\begin{array}{l}\text { - Document } \\
\text { - Counsel supplier }\end{array}$ & None & Discretionary \\
\hline $\begin{array}{l}\text { Supplier } \\
\text { Nonconformance }\end{array}$ & Minor & $\begin{array}{l}\text { Satisfactory } \\
\text { (Not Affected) }\end{array}$ & $\begin{array}{l}\text { - Document } \\
\text { - Counsel supplier } \\
\text { - Review disposition } \\
\text { - Review CA (if needed) }\end{array}$ & None & $\begin{array}{l}\text { - Respond by dispositioning } \\
\text { SCN } \\
\text { - Submit \& implement } \\
\text { CA (discretionary) }\end{array}$ \\
\hline Probation & Major & $\begin{array}{l}\text { Conditional } \\
\text { (Qualified) }\end{array}$ & $\begin{array}{l}\text { - Document } \\
\text { - Obtain procurement } \\
\text { concurrence } \\
\text { - Notify supplier } \\
\text { - Evaluate appeal } \\
\text { - Approve CA } \\
\text { - Resolve probation }\end{array}$ & - Sign probation notice & $\begin{array}{l}\text { - Respond by: } \\
\text { Appeal } \\
\text { or } \\
\text { Submit \& implement } \\
\text { CA (mandatory) }\end{array}$ \\
\hline Suspension & Critical & $\begin{array}{l}\text { Suspended } \\
\text { (On Hold) }\end{array}$ & $\begin{array}{l}\text { - Document } \\
\text { - Notify Procurement } \\
\text { - Evaluate appeal } \\
\text { - Approve CA } \\
\text { - Resolve suspension }\end{array}$ & $\begin{array}{l}\text { - Notify Supplier } \\
\text { - Issue Stop Work Order } \\
\text { - Forward CA to PE Office } \\
\text { - Lift Stop Work Order }\end{array}$ & $\begin{array}{l}\text { - Respond by: } \\
\text { Appeal } \\
\text { or } \\
\text { Submit \& implement } \\
\text { CA (mandatory) }\end{array}$ \\
\hline $\begin{array}{l}\text { Termination of } \\
\text { Approval }\end{array}$ & Fatal & $\begin{array}{l}\text { Terminated } \\
\text { (Revoked) }\end{array}$ & $\begin{array}{l}\text { - Document } \\
\text { - Notify procurement } \\
\text { - Recind supplier } \\
\text { approval \& PE program } \\
\text { participation }\end{array}$ & $\begin{array}{l}\text { - Notify Supplier } \\
\text { - Issue Stop Work Order } \\
\text { - Terminate contract } \\
\text { (discretionary) }\end{array}$ & $\begin{array}{l}\text { Reapply through } \\
\text { supplier approval } \\
\text { process }\end{array}$ \\
\hline
\end{tabular}


Rev. 0

the severity.of the problem and its impact on data quality. A required corrective action date will be assigned if the probation must be resolved within a certain time frame to prevent generation of deliverables which do not meet INEL PE program requirements. Project DQOs shall also be considered.

Within the response time allowed, the supplier must provide the PE Program Manager with one of the following: a corrective action plan for resolving the problem invoking the probation and an anticipated closure date; evidence that the problem invoking the probation action has already been resolved internally by the supplier; or a written appeal of the probation action by presenting all evidence showing why the probation action is in error: A supplier may not appeal for one reason, then appeal at a later date for a different reason on the same probation action.

If evidence supporting an appeal or closure of corrective action is approved by the PE Program Office, the probation is rescinded. Rescinding the probation action returns the supplier to satisfactory status. In the case of a successful appeal, the probation is not counted against the supplier for tracking purposes. If the appeal is denied by the PE Program Office, the supplier probation is enforced, and corrective action is required. Acceptance or denial of an appeal is the sole prerogative of the PE Program Manager.

Identification of appropriate corrective action strategies and their implementation is the responsibility of the supplier. However, in cases involving probation resolution, the PE program office must approve the corrective action, and may overrule the supplier to require that specific corrective actions occur. After supplier notification, the PE Program Office communicates with the supplier to negotiate or recommend corrective actions. At this time, a corrective action closure date is agreed upon if it has not been previously specified by the PE Program Office.

When the PE program office (i.e., manager and QAO) approves the supplier's submitted corrective action plan, the supplier remains on probation until the corrective action is completed and evidence of closure is submitted to the PE Program Office. Successful analysis of a blind PE material may be required, depending upon the nature of the problem and associated corrective action. If the corrective action is not closed by the required corrective action closure date, the supplier will be placed on suspension until the corrective action is closed.

If after successful closure of a probation, six months of active support pass without incurring another probation based on the same indicator (i.e., recurrence of an SNC), the probation tally for that indicator is set back to zero for purposes of determining performance status.

\subsubsection{Supplier Suspension}

Suppliers are placed on suspension when their performance does not meet INEL PE program requirements in one or more areas, causing the quality of their product to be severely compromised or unusable. The supplier's SMO approval is suspended until mandatory corrective action to address the cause(s) is satisfactorily completed (i.e., closed). Use of the supplier for affected services during the suspension period is prohibited. Failure to correct the cause of the suspension will result in permanent revocation of the supplier's SMO approval.

Grounds for suspending an analytical service supplier are listed in Tables 5-1 and 5-2. At the request of the PE Program Office, EG\&G Procurement notifies the supplier of the suspension by FAX, followed by official written notification. Suspension notices must identify the 
scope of the suspension (e.g., analyte, method, analytical discipline, entire supplier), the grounds for invoking suspension, and a time frame for supplier response. Suspension status becomes effective when EG\&G Procurement makes the initial notification (FAX) to the supplier.

Concurrently with the Suspension notice, EG\&G Procurement issues a Stop Work Order to prohibit the supplier from performing any further work in the affected areas under the SMO contract until the suspension is resolved. Instructions for the disposition of work in-house but not started and work in process are included in the Stop Work Order. In some cases, the supplier may be instructed to finish any work in process if the INEL PE Program Office determines that any alternatives will have greater negative impact on project data quality objectives (DQOs). For example, an analytical laboratory might be instructed to finish any work if process if the alternative of sending it to another laboratory would cause a holding time violation. If the supplier is instructed to ship samples to an alternate supplier, the shipment will be at the expense of the suspended supplier.

The amount of time allowed for supplier response is determined by the PE Program office. The amount of time allowed for response depends upon the severity of the problem and its impact on project DQOs.

Within the response time allowed, the supplier must provide EG\&G Procurement with one of the following: a corrective action plan for resolving the problem invoking the suspension; evidence that the problem invoking the suspension action has already been resolved internally by the supplier; or an appeal of the suspension action by presenting evidence showing why the suspension action is in error. After receiving the supplier response, EG\&G Procurement forwards it to the PE Program Office for approval.

If evidence supporting an appeal or closure of corrective action is approved by the PE Program Office, the PE Program instructs EG\&G Procurement to rescind the suspension and the Stop Work order. The supplier is returned to satisfactory status. In the case of a successful appeal, the suspension is not counted against the supplier for tracking purposes. If the appeal is denied by the PE Program Office, the supplier suspension is enforced, and corrective action is mandatory.

Identification of appropriate corrective action strategies and their implementation is the responsibility of the supplier. However, in cases involving suspension resolution, the PE program office must approve the corrective action, and may overrule the supplier to require that specific corrective actions occur. After EG\&G Procurement has notified the supplier of the suspension action, the PE Program Office may communicate freely with the supplier to negotiate or recommend corrective actions and to agree to a corrective action closure date. Any changes in supplier response or due dates because of this negotiation must be resubmitted to EG\&G Procurement.

Once the PE program office (i.e., Manager and QAO) approves the supplier's submitted corrective action plan, the supplier remains on suspension until the corrective action is completed and evidence of closure is submitted to EG\&G Procurement and the PE Program Office. Successful analysis of a blind PE material may be required, depending upon the nature of the problem and associated corrective action. If the corrective action is not closed by the negotiated corrective action closure date, the supplier's SMO approval will be terminated. 
Rev. 0

After a supplier has successfully fulfilled the requirements to resolve a suspension (i.e., corrective action and performance demonstration), EG\&G Procurement, at the direction of the PE Program Office, notifies the supplier that their performance status is returned to satisfactory and lifts the Stop Work order. If after successful closure of a suspension, six months of active support pass without incurring another suspension. based on the same indicator (i.e. recurrence of an SNC), the suspension tally for that indicator is set back to zero for purposes of determining performance status.

\subsubsection{Termination of SMO Approval}

SMO approval is terminated for suppliers whose performance is determined to be unacceptable under the requirements of the PE program. Because the supplier's SMO approval is permanently revoked, no further work under the SMO subcontract will be sent to the supplier.

Grounds for terminating a supplier's SMO approval are listed in Tables 5-1 and 5-2. Notification of SMO approval termination will be made to the supplier, in writing, by EG\&G Procurement at the request of the PE program manager. Termination notices must identify the areas (e.g., analyte, method, analytical discipline, entire supplier) affected by the termination and the grounds for terminating SMO approval. Because termination of SMO approval is a last resort, and multiple opportunities have been previously provided to correct the problem, no supplier response time is allowed. EG\&G Procurement issues an immediate Stop Work order to prohibit further use of the supplier under the SMO subcontract in the areas affected by the termination.

Termination of SMO approval should not be confused with subcontract termination. Because the supplier is no longer SMO approved, the supplier is not eligible to receive work under the terms of the subcontract. If the supplier desires to have SMO approval reinstated, the supplier must reapply through the initial SMO approval process. ${ }^{c}$ If SMO approval is reinstated, the supplier may again provide services in accordance with the subcontract. Any costs incurred or associated with the reapproval process must be borne by the supplier.

The decision to terminate the subcontract of a service supplier whose SMO approval has been terminated is solely the purview of EG\&G Procurement.

\subsection{Reporting of Performance Assessments and Status}

Results of performance assessments (indicator analyses) will be documented in a report to management. These reports shall be distributed to the analytical service suppliers, the PE Program QAO, EG\&G Procurement and any interested INEL or DOE-ID parties on a quarterly basis (see Section 7.3). At a minimum, these reports shall include a summary of trend conditions, supplier nonconformances and corrective actions, probation notifications and status, suspension notifications and status, PE program(s) results (external to INEL), real time PE sample data information (if applicable), indicator trending information, and current supplier status. Program managers may request more frequent reports depending on project schedule and duration.

c. SMO-SOP-12.2.1, Analytical Service Supplier Approval Process, is in draft form. 
Rev. 0

In order to maintain supplier confidentiality, identification codes will be established for each supplier. Reports sent to suppliers will use the identification codes for supplier identification. 


\section{RECORDS MANAGEMENT AND RETENTION}

\subsection{Documentation Requirements}

Cross-referenced files which contain performance indicator data, statistical analyses and control charts, and laboratory performance status data shall be maintained. The data are crossreferenced by analytical service supplier, analysis method, and analyte, as appropriate.

The ERD Records Management Plan ${ }^{18}$ incorporates the State and Federal requirements for records management supporting environmental investigations. It provides guidance for identification, control, and retention of records. Requirements for document control and quality records are specified in ERD QPP $-149,{ }^{19}$ and the EG\&G Idaho Quality Manual. ${ }^{20}$ Two ERD $\mathrm{PDs}^{7}$ address records management: ERD PD 1.8, "Administrative Record," and ERD PD 1.9, "Records Management." Records generated as a result of the implementation of this management plan shall be maintained in ARDC according to applicable requirements.

Retention periods for project file records are specified in the ERD Records Management Plan. ${ }^{17}$ Originators may also specify retention periods; in case of discrepancy, the longest retention period applies. Records shall be designated as quality records if they contain information that is critical to the assessment of quality of a supplier of services. At a minimum, the quarterly reports to management, nonconformance reports and resolution documentation, probation and suspension communications, and PE sample certification data (validation and statistical analysis) shall be considered quality records for this program.

\subsection{Computer Databases, Statistical Software, and Networks}

Performance indicator data shall be maintained, tracked and trended in the Integrated Environmental Data Management System (IEDMS). Statistical analysis of performance indicator data shall be performed using commercially-available statistical software packages. Databases and software packages used to maintain PE Program data files shall be documented and verified appropriately by the performing organizations.

IEDMS applications must conform to existing requirements documentation. ${ }^{21,22}$ The IEDMS performing organization shall address the applications supporting this program in appropriate documents [e.g., software quality assurance plan(s) and software configuration management plan(s)]. In addition, operating procedures (OPs) ${ }^{23}$ shall ensure the integrity of the IEDMS. 


\section{QUALITY ASSURANCE REQUIREMENTS}

\subsection{Program Requirements}

The PE Program shall meet appropriate quality requirements specified in QPP-149, Quality Program Plan for the Environmental Restoration Program, ${ }^{19}$ the EG\&G Idaho Quality Manual, ${ }^{20}$ EG\&G Idaho Company Procedures ${ }^{25}$ and Environmental Restoration Program Directives. ${ }^{7}$ Quality requirements for PESM production are defined in a QAPjP. ${ }^{11}$

\subsection{Nonconformances and Corrective Actions}

Programmatic nonconformances, corrective actions, and conditions adverse to quality occurring within EG\&G shall be documented and resolved per the requirements of the following documents:

- EG\&G Company Procedure 9.7, "Nonconformances"

- EG\&G Company Procedure 1.6, "Root Cause Analysis"

- EG\&G Quality Manual, QP-16, "Corrective Action"

- Environmental Restoration Department PD 5.13, "Corrective Action"

- Environmental Restoration Department PD 5.14, "Quality Program Monitoring and Surveillance"

- Environmental Restoration Department PD 5.18, "Conditions Adverse to Quality."

The PE Program Manager is responsible for ensuring that all nonconformances, corrective actions, and conditions adverse to quality are resolved in a timely fashion.

Supplier nonconformances and corrective actions are described in Section 5. The PE project office shall communicate with the analytical suppliers prior to and throughout the nonconformance and corrective action processes.

\subsection{QA Reports to Management}

Quarterly reports summarizing supplier performance indicators and performance status shall be prepared by the PE Program QA Officer and the PE Program Manager and submitted according to the requirements of Section 5.3. A copy of the report is sent to supplier QA officers.

The PE Program Manager shall provide reports on a quarterly basis to appropriate project managers which summarize performance indicators and performance status of analytical support suppliers. Reports to project managers shall be restricted to these quarterly reports unless a condition impacting project DQOs occurs in the interim. Project managers shall be informed immediately if supplier nonconformances are identified that will impact project ability to meet DQOs. An example of this circumstance is real-time PE sample results that are outside 
EGG-ER-11005

Rev. 0

established control limits. The program managers may-request monthly or weekly reports, depending upon program schedule, design, and duration. 


\section{ASPEP IMPLEMENTATION}

The implementation schedule for the ASPEP is shown in Figure 8-1. Program implementation will be phased over the next two fiscal years, starting with use of existing systems (e.g., use of SCMs, existing PE program data, performance indicator charts) followed by development of appropriate implementing documentation and additional PE tools, and execution of a pilot phase.

\subsection{Implementing Documentation}

Implementing procedures for the ASPEP will be prepared and documented throughout fiscal year 1994 and into fiscal year 1995 as required. The implementing procedures will be documented as SOPs, SOWs, and QAPjP, as appropriate, for data management, program management, and PE tool preparation. Document revision requests will be implemented when process improvements are identified. At a minimum, document review will occur annually to identify needed revisions.

\subsection{Performance Evaluation Tools}

Concurrent development of custom prepared PE materials (e.g., aqueous PE samples and PESMs) or acquisition of commercially available PE samples for assessing analytical laboratory service supplier performance will occur as funding permits. SCM use will occur per DOE-ID policy or as negotiated by individual ER project manager teams. The LCS PESM set will be distributed in FY 1994 to radiochemical and metals analytical laboratories currently performing work in support of INEL ER projects. The preparation of additional PESM sets and associated documentation will continue in FY 1994 and out years as long as the need exists within the ER\&WM program.

Candidate blind test data packages for use in evaluating validation suppliers will be identified and archived. These test packages will be selected from data packages received in support of INEL projects. Selection will be based on analysis type and program (e.g., environmental monitoring, ER, RCRA).

\subsection{Pilot Phase}

A pilot phase identifying program strengths and weaknesses will provide a mechanism to assess the usefulness of the requirements and optimize the processes prior to official implementation. The pilot phase will be initiated when the new laboratory and data validation service master subcontracts go into effect (scheduled for December 1994) and will continue for at least six months. After six months, the pilot phase will be evaluated to determine if the systems are working as intended, and may be extend to one year duration if further optimization is required.

At a minimum, indicators shall be tracked, trended, and the reported results used as counseling tools during the pilot phase. External PE program participation as defined in Section 3 will be required during the pilot. Tracking and trending of performance indicators will be implemented in the following order: (1) general performance indicators (laboratory and data validation), (2) existing PE programs, (3) routine laboratory $\mathrm{QC}$, and (4) real-time blind PE 


\begin{tabular}{|c|c|c|c|c|c|c|c|c|c|c|c|c|c|c|c|c|c|c|c|c|}
\hline & \multicolumn{12}{|c|}{ FISCAL YEAR 1994} & \multicolumn{4}{|c|}{ FISCAL YEAR 1995} & \multicolumn{4}{|c|}{ FISCAL VEAR 1996} \\
\hline & 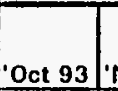 & 'Nov 93 | & |Dec 93 & Jan 94 & |Fob 94 & Mar 94 & |Apr $94 \mid$ & |'May 9 & |Jum 94]: & Jul 94 & |:Auv 94]: & a|'Sop 94 & \begin{tabular}{|c|c|} 
oct.Dec \\
94
\end{tabular} & \begin{tabular}{|l|} 
Jan-Mar \\
95
\end{tabular} & $\begin{array}{l}\text { Apr.Jun } \\
95 \\
\end{array}$ & $\begin{array}{c}\text { Jul-Sen } \\
95\end{array}$ & \begin{tabular}{|c|} 
oct-Doc \\
95
\end{tabular} & $\begin{array}{c}\text { Jan-Mar } \\
96\end{array}$ & $\begin{array}{c}\text { Apr.Jun } \\
96\end{array}$ & \begin{tabular}{|c|} 
Jul. Sop \\
96
\end{tabular} \\
\hline \multicolumn{21}{|c|}{ 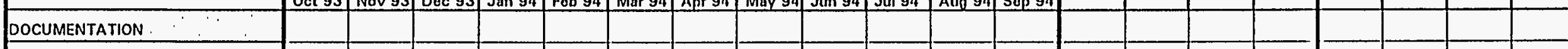 } \\
\hline ASPEP & 二 & & & & & + & & & & & & & & & & & & & & \\
\hline \multicolumn{21}{|l|}{ Implementing Documentation } \\
\hline \multicolumn{21}{|l|}{ Data Management } \\
\hline \multicolumn{21}{|l|}{ Statistical Analysis } \\
\hline \multicolumn{21}{|l|}{ Propram Management } \\
\hline \multicolumn{21}{|l|}{ PE TOOLLS } \\
\hline \multicolumn{21}{|l|}{ sows } \\
\hline \multicolumn{21}{|l|}{ Diluent Soil Prep } \\
\hline \multirow{2}{*}{\multicolumn{21}{|c|}{$\begin{array}{l}\text { PESM Set Proparation } \\
\text { Other Lab PE Tools }\end{array}$}} \\
\hline \multirow{2}{*}{\multicolumn{21}{|c|}{$\begin{array}{l}\text { Othar Lab PE Tools } \\
\text { Validation Test Packages }\end{array}$}} \\
\hline \multicolumn{15}{|l|}{ Validation Test Packages } & & & & & & \\
\hline Real Time Soil & & & \multicolumn{2}{|c|}{ - ScM use } & & & & - LCs use & se- & & & $-]^{-}$ & & & PESM use & soc- & & & & $=$ \\
\hline Real Timo Water & & & & & & & & & & & & & & & & $=$ & $=$ & & - & $=8$ \\
\hline Real Tima Other Matrics & & & & & & & & & & & & & & & & $=$ & I & & $E$ & $\Longrightarrow$ \\
\hline \multicolumn{21}{|l|}{ PLOT PHASE , O } \\
\hline Contract Award & & & & & & & & & & & & & $\%$ & & & 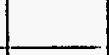 & . & & & - \\
\hline \multicolumn{21}{|l|}{ T\&T Indicators } \\
\hline \multicolumn{21}{|l|}{ Goneral indicators } \\
\hline \multicolumn{21}{|l|}{ PE Prog. Results } \\
\hline \multirow{2}{*}{\multicolumn{21}{|c|}{$\begin{array}{l}\text { Routine Lab OC } \\
\text { Blind PE Results }\end{array}$}} \\
\hline Blind PE Results & & & & & & & & & & & & & & & - & $=$ & & & & \\
\hline \multicolumn{21}{|l|}{ Data Managomont Approach } \\
\hline \multicolumn{21}{|l|}{ Pillot Phaso Assessment } \\
\hline \multicolumn{21}{|l|}{ Termination of Pilot Phase } \\
\hline FULL IMPLEMENTATION & eefficative & upon pil & lot tormin & |atton! & & & & & & & & & & & & - & & & & \\
\hline Indicator Tracking and Trending & & & & & & & & & & & & & & & $=$ & $=$ & E & & & \\
\hline Program Documentation Review & and Update & & & & & & & & & & & _ & & & $=$ & $=$ & E & $=$ & $\bar{I}$ & $\Longrightarrow$ \\
\hline Roports to suppliers & & & & & & & & & & & & & & & & & & & & \\
\hline
\end{tabular}

Figure 8-1. Implementation schedule for ASPEP. 
materials. Within each of these areas tracking and trending of metals and radiochemistry indicators will be implemented first, followed by those for organics and classical analyses.

Analytical service suppliers shall be held fully accountable to the requirements described in the ASPEP upon completion of the pilot (i.e., after full implementation of the ASPEP). 


\section{REFERENCES}

1. J. Fisk, EPA Analytical Operations Branch, to CLP and SAS Laboratories, Subject: "Joint Statement on Fraud in the Community of Contractors for Analysis of Environmental Samples," August 9, 1991.

2. Code of Federal Regulations, 40 CFR Part 300, "OSWER Procedures for Contract Laboratory Program Investigations," Office of the Federal Register, May 1992.

3. EPA, Contract Laboratory Program Statement of Work for Inorganic Analysis Multi-Media Multi-Concentration, ILM01.x, most recent revision.

4. EPA, Test Methods for Evaluating Solid Waste, Physical/Chemical Methods, SW-846, most recent updates.

5. EPA, Methods for Chemical Analysis of Water and Wastes, PB84-128677, March 1983.

6. EPA, Contract Laboratory Program Statement of Work for Organic Analysis Multi-Media Multi-Concentration, OLM01.x, most recent revision.

7. ERD, Environmental Restoration Program, Program Directives Manual, current revision.

8. ERD, Sample Management Office, Standard Operating Procedures, SMO-SOP-12.1.1, "Levels of Method Validation."

9. DOE, Quality Assurance Program Plan for the Waste Isolation Pilot Plant Experimental-Waste Characterization Program, DOE/EM/48063-1, July 1991.

10. DOE, Performance Demonstration Program Plan for the WIPP Experimental-Waste Characterization Program, DOE/WIPP 91-016, Waste Isolation Pilot Plant, Carlsbad, New Mexico.

11. EG\&G Idaho, Inc., 1993, Quality Assurance Project Plan for the Development of Idaho National Engineering Laboratory Site-Specific Performance Evaluation Soil Materials, EGG-ER-10720, MONTH 1993.

12. EG\&G Idaho Inc., 1993, Statement of Work for the Development of Idaho National Engineering Laboratory-Specific Soil Performance Evaluation Materials, ER-SOW-126, MONTH 1993.

13. EG\&G Idaho, Inc., 1993, Statement of Work for Inorganic and Radiological Characterization of the INEL Laboratory Control Sample Performance Evaluation Soil Material, ER-SOW-141, MONTH 1993.

14. Environmental Restoration Department, Sample Management Office, Standard Operating Procedures, SMO-SOP-12.1.2, "Rádiological Data Validation." 
EGG-ER-11005

Rev. 0

15. Environmental Restoration Department, Sample Management Office, Standard Operating Procedures, SMO-SOP-12.1.3, "Validation of Volatile and Semi-Volatile Organic Gas Chromatography/Mass Spectrometry Data."

16. Environmental Restoration Department, Sample Management Office, Standard Operating Procedures, SMO-SOP-12.1.4, "Validation of Gas Chromatographic Data."

17. Environmental Restoration Department, Sample Management Office, Standard Operating - Procedures, SMO-SOP-12.1.5, "Inorganic Data Validation."

18. EG\&G Idaho, Inc., Idaho National Engineering Laboratory Environmental Restoration Program Records Management Plan for EG\&G Idaho, EGG-WM-9742, January 1992.

19. EG\&G Idaho, Inc., Quality Program Plan for the Environmental Restoration Program, QPP-149, Revision 3, 1993.

20. EG\&G Idaho Inc., Quality Manual, current issue.

21. EG\&G Idaho, Inc., 1993, Software Quality Assurance Plan for the Environmental Restoration and Waste Management Department, EGG-ER-10860, 1993.

22. EG\&G Idaho, Inc., 1993, Environmental Restoration and Waste Management Department Software Configuration Management Plan, EGG-ER-10777, 1993.

23. Engineering and Research Applications Department, Statistics Reliability and Analysis Unit, IEDMS Operating Procedures.

24. E\&G\& Idaho, Inc., Company Procedures Manual, current issue. 